\title{
Core Fucosylation of the T Cell Receptor Is Required for T Cell Activation
}

\begin{abstract}
Wei Liang ${ }^{1 \dagger}$, Shanshan Mao't, Shijie Sun ${ }^{1 \dagger}$, Ming $\mathrm{Li}^{1}$, Zhi $\mathrm{Li}^{2}$, Rui Yu', Tonghui Ma', Jianguo $\mathrm{Gu}^{3}$, Jianing Zhang ${ }^{4}$, Naoyuki Taniguchi ${ }^{5}$ and Wenzhe $\mathrm{Li}^{1 *}$

${ }^{1}$ College of Basic Medical Sciences, Dalian Medical University, Dalian, China, ${ }^{2}$ Clinical Laboratory, Dalian Municipal Central Hospital, Dalian, China, ${ }^{3}$ Division of Regulatory Glycobiology, Institute of Molecular Biomembrane and Glycobiology, Tohoku Medical and Pharmaceutical University, Sendai, Japan, ${ }^{4}$ School of Life Science and Medicine, Dalian University of Technology, Panjin, China, ${ }^{5}$ Systems Glycobiology Research Group, Advanced Science Institute, RIKEN, Saitama, Japan
\end{abstract}

$\mathrm{CD}^{+} \mathrm{T}$ cell activation promotes the pathogenic process of systemic lupus erythematosus (SLE). T cell receptor (TCR) complex are highly core fucosylated glycoproteins, which play important roles in T cell activation. In this study, we found that the core fucosylation of $\mathrm{CD} 4^{+} \mathrm{T}$ cells was significantly increased in SLE patients. Loss of core fucosyltransferase (Fut8), the sole enzyme for catalyzing the core fucosylation of $\mathrm{N}$-glycan, significantly reduced $\mathrm{CD} 4^{+} \mathrm{T}$ cell activation and ameliorated the experimental autoimmune encephalomyelitis-induced syndrome in Fut8 ${ }^{-/}$mice. T cell activation

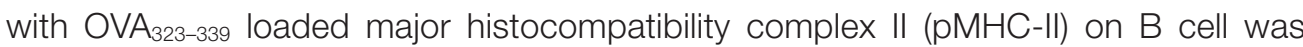
dramatically attenuated in Fut8 ${ }^{-/-} \mathrm{OT}-\mathrm{II} \mathrm{CD}^{+}+\mathrm{T}$ cells compared with Fut8 ${ }^{+/+} \mathrm{OT}-\mathrm{II}$ $\mathrm{CD}^{+} \mathrm{T}$ cells. Moreover, the phosphorylation of ZAP-70 was significantly reduced in Fut $8^{+/+} \mathrm{OT}-\| \mathrm{CD} 4^{+} \mathrm{T}$ cells by the treatment of fucosidase. Our results suggest that core fucosylation is required for efficient TCR-pMHC-II contacts in CD4+ $\mathrm{T}$ cell activation, and hyper core fucosylation may serve as a potential novel biomarker in the sera from SLE patients.

Keywords: core fucosylation, $\mathrm{T}$ cell receptor, $\mathrm{T}$ cell activation, systemic lupus erythematosus, T-B cell interaction

\section{INTRODUCTION}

Systemic lupus erythematosus (SLE) is a severe autoimmune disease that characterized by the production of autoantibodies and the subsequent inflammatory disorders (1). Although the pathogenesis is not completely understood, the activation of $\mathrm{CD} 4^{+} \mathrm{T}$ cells seems plays an essential role in the onset and development of SLE (2). Appropriate CD4 ${ }^{+} \mathrm{T}$ cell activation is crucially important for adaptive immune responses and autoimmunity, but hyper-activation of these cells results in autoimmune diseases. T cell recognition of peptide-loaded major histocompatibility complex II (pMHC-II) on the antigen-presenting cells (APCs) by T cell receptors (TCRs) is the most important checkpoint for $\mathrm{CD}_{4}{ }^{+} \mathrm{T}$ cell activation (3). During antigen recognition, the CD4 coreceptor binds to the non-polymorphic surfaces of the membrane-proximal domains of the same pMHCs, which results in a marked increase in the sensitivity of T cells to pMHCs on APC. When adequate agonistic TCR signaling creates a favorable microenvironment for binding, CD28-B7 molecules provide costimulatory lower the thresholds for TCRs triggering and activation. The signaling through TCR induces a conformational change in leukocyte function-associated antigen- 1 , which greatly 
increases its affinity for intercellular adhesion molecule 1 and contributes to immune synapse formation T cells and APC $(4,5)$.

Glycosylation plays a regulatory and often pivotal role in $\mathrm{T}$ cell activation (6-10). Several studies have reported that glycosylation could contribute to higher activation thresholds of $\mathrm{T}$ cells. For instance, $\beta 1,6 \mathrm{~N}$-acetylglucosaminyltransferase $\mathrm{V}$ (Mgat5) deficiency mediates lower T lymphocyte activation thresholds, and subsequently improves $\mathrm{T}$ cell activity in vitro and results in autoimmune disease in vivo $(11,12)$. Deletion of sialyltransferase ST3Gal-1 increase the sensitivity of TCRs to low-affinity ligands in $\mathrm{CD}^{+} \mathrm{T}$ cells (13). Fucosyltransferase 1 transgenic mice show increased TCR signaling and apoptosis that results in thymocyte maturation arrest (14). Notably, reduced $\mathrm{N}$-glycosylation of TCR chains can improve functional avidity and recognition by $\mathrm{T}$ cells (15) suggesting that the glycosylation of TCR has a unique role in the regulation of T cell activation.

$\mathrm{T}$ cell receptors are heavily core-fucosylated glycoproteins. The core fucosylation of protein is catalyzed by core fucosyltransferase (Fut8), which transfers fucose residue from GDPfucose to the innermost $\mathrm{N}$-acetylglucosamine (GlcNAc) residue of N-linked glycans via an $\alpha 1,6$ linkage in the Golgi apparatus of mammalians (Figure S1 in Supplementary Material). Fut8mediated core fucosylation is an important post-translational process (16), which regulates protein conformation, stability, and functional expression. Studies have shown that the N-glycans at $\mathrm{Asn}^{70}$ [GlcNAc( $\left.\alpha 1,6 \mathrm{Fuc}\right)-\beta 1,4 \mathrm{GlcNAc:}$ (A2G2F)], $\mathrm{Asn}^{185}$ (A2G2F), and $A_{s n}{ }^{203}$ in the $\alpha$ chain $(\mathrm{C} \alpha)$ and $A \mathrm{sn}^{236}$ in the $\beta$ chain $(\mathrm{C} \beta)$ extend from the surface of TCR on Drosophila melanogaster cells $(6,17)$. Interestingly, they found that the C $\alpha$ and C $\beta$ of TCR were connected by the hydrogen bonds of the core fucose residue from $\operatorname{Asn}^{185 \alpha}(\mathrm{A} 2 \mathrm{G} 2 \mathrm{~F})$ to side chains of $\operatorname{Glu}^{181 \beta}$ and $\operatorname{Ser}^{182 \beta}(6,17)$, suggesting a crucial role of core fucosylation on the conformation of TCR. However, to the best of our knowledge, none of the previous studies had addressed the regulatory role of TCR core fucosylation on $\mathrm{CD} 4^{+} \mathrm{T}$ cell activation.

$\mathrm{B}$ cells play a role in evoking $\mathrm{T}$ cell responses by functioning as APCs, and the presentation of peptide by MHC-II on the $\mathrm{B}$ cells initiates $\mathrm{T}$ cell activation (18). Therefore, it is reasonable to anticipate that the core fucosylation has significant functional implications in T-B cell interaction, and thus affect the $\mathrm{CD} 4^{+}$ $\mathrm{T}$ cell activation. In this study, we provide the first confirmation that SLE patients exhibited hyper core fucosylation on $\mathrm{CD} 4^{+}$ T cells, which significantly enhanced the activation of their $\mathrm{CD} 4^{+}$ $\mathrm{T}$ cells. Knockout of Fut8 gene resulted in attenuated T-B cell interaction via TCR-pMHC and the consequential reduced $\mathrm{CD} 4^{+}$ $\mathrm{T}$ cell activation. Our data suggest that the core fucosylation may serve as a potential novel biomarker with promising clinical and therapeutic implications in SLE patients.

\section{MATERIALS AND METHODS}

\section{Mice}

Fut $8^{-/-}$mice were generated as previously described (19), and homozygous wild-type $\left(\right.$ Fut $8^{+/+}$) and Fut $8^{-/-}$mice on the C57BL/6 background were obtained by crossing heterozygous
Fut $8^{+/-}$mice (C57BL/6). OT-II (Jackson Laboratory) is a C57BL/6 TCR transgenic strain, expressing a receptor specific for peptide $\mathrm{OVA}_{323-339}$. Fut $8^{+/+} \mathrm{OT}$-II mice and Fut $8^{-/-} \mathrm{OT}$-II mice were generated by crossing heterozygous Fut $8^{+/}$OT-II mice. Mice were maintained in the specific pathogen-free laboratory animal facility of Dalian Medical University. All animal work was approved by the Ethics Committee at the Dalian Medical University.

\section{Patients}

Serum samples were collected from a total of 17 SLE patients (14 women, 3 men; mean age, 49 years; range, 18-67 years) with and healthy controls (12 women, 12 men; mean age, $18-48$ years) (Table S1 in Supplementary Material). The diagnosis of underlying disease was made based on clinical manifestation, serology, imaging, and/or histopathology. These participants were Chinese, recruited at Dalian municipal central hospital. The antinuclear antibodies (ANA) titers of $\mathrm{AD}$ patients were detected with using Anti-nuclear Antibodies IgG Kit (EUROIMMUN, Germany). The Ethics Committee at the hospital approved the study protocol.

\section{Antibodies}

Anti-CD16/32 (2.4G2), anti-CD3(145-2c11), anti-CD28 (37.51), FITC-anti-MHC II (M5/114.15.2), FITC-anti-CD69 (H1.2F3), PE-labeled anti-CD4 (GK1.5), APC-labeled anti-CD8 (53-6.7), biotin-labeled anti-TCR $\beta$ (H57-597), and PE-Cy5-labeled antiTCR $\beta$ (H57-597) were obtained from e-Bioscience; anti-GAPDH, horseradish peroxidase (HRP)-conjugated goat anti-mouse IgG and HRP-conjugated donkey anti-human IgG were obtained from proteintech; additional biotin-conjugated lens culinaris agglutinin (LCA) were purchased from Vector; anti-TCR $\alpha \beta$ (ab25336), anti-pZAP70 (ab194800), anti-ZAP70 (ab32410), Natural streptavidin protein (FITC) (ab136201), and streptavidin (HRP) (ab7403) were purchased from Abcam.

\section{Histological Analysis}

Formalin-fixed tissue samples were paraffin-embedded and sections were analyzed by hematoxylin-eosin (H\&E) staining. The sections were stained with biotin-conjugated LCA. Briefly, sections were deparaffinized three times in xylene and hydrated through a $100,90,80$, and $70 \%$ ethanol to phosphate-buffered saline (PBS). To quench the endogenous peroxidase activity, slides were incubated with $3 \% \mathrm{H}_{2} \mathrm{O}_{2}$ for $30 \mathrm{~min}$. Then, the slides were incubated with biotin-conjugated LCA, and washed three times with PBS. The slides probed with HRP-streptavidin for $30 \mathrm{~min}$, and visualized with 3,3'-diaminobenzidine. The intensity of LCA-positive staining in the spleen was analyzed by integrated optical density using Image-Pro ${ }^{\circledR}$ Plus software (version 6.0; Media Cybernetics, USA).

\section{Cell Lysate}

Cells were solubilized in lysis buffer [Tris-HCl (50 mM), 1\% Triton X-100, 10\% glycerol, phenylmethylsulfonylfluoride $(100 \mu \mathrm{M})$, leupeptin $(5 \mu \mathrm{g} / \mathrm{mL})$, aprotinin $(1 \mu \mathrm{g} / \mathrm{mL}), \mathrm{NaF}$ (100 mM), $150 \mathrm{mM} \mathrm{NaCl}, 2 \mathrm{mM}$ EDTA, and sodium orthovanadate $(1 \mathrm{mM})]$ for $15 \mathrm{~min}$ at $4^{\circ} \mathrm{C}$. Cell lysate was centrifuged at 
$20,000 \times g$ for $10 \mathrm{~min}$ at $4^{\circ} \mathrm{C}$, and the supernatant was subjected to immunoprecipitation or Western blot, as indicated below.

\section{Fut8 Enzyme Activity Assay}

The Fut8 enzyme activity was measured by using the previous method (20). Five micrograms cell lysates as the enzyme source were added to the assay buffer (200 mM MES, $1 \%$ Triton X-100) supplemented with donor (500 $\mu \mathrm{M}$ GDP-L-fucose) and substrate [50 $\mathrm{M}$ GnGn-Asn-4-(2-pyridylamine) butylamine (PABA)]. The mixture was incubated at $37^{\circ} \mathrm{C}$ for $8 \mathrm{~h}$, and the reaction was stopped by heating at $100^{\circ} \mathrm{C}$ for $5 \mathrm{~min}$. The reactive solution was then centrifuged at $12,000 \times g$ for $10 \mathrm{~min}$, and $10 \mu \mathrm{L}$ of the reaction products were subjected to high-performance liquid chromatography (HPLC) with a Fluorescent detector (Waters Corporation, USA). The excitation and emission wavelengths are 320 and $400 \mathrm{~nm}$, respectively.

\section{PCR Array}

Total RNAs were extracted from $\mathrm{Fut}^{+/+}$SPLs and Fut8 ${ }^{-/-}$SPLs with TRIzol reagent (Takara Bio). Mouse T Cell and B Cell Activation PCR Array (SA Biosciences) was carried out according to the protocol of the manufacturer. The difference of gene expression between $\mathrm{Fut}^{+/+}$SPLs and $\mathrm{Fut}^{-/-}$SPLs was calculated.

\section{Animal Immunization}

Mouse was immunized by subcutaneous injection with $200 \mu \mathrm{g}$ OVA mixed with an equal volume of complete Freund's adjuvant (CFA) (Sigma). Two weeks later, mice were immunized with $200 \mu \mathrm{g}$ OVA by subcutaneous injection. Mice sera were collected at 0,7 , and 14 days post-immunization.

\section{Enzyme-Linked Immunosorbent Assay (ELISA)}

The concentrations of IL-2 analyzed using mouse IL-2 ELISA kits (Boster Biological Engineering, Wuhan, China), according to the manufacturer's instructions. The concentrations of IL-2 were calculated according to a standard curve prepared using samples of known concentration. The absorbance was measured at a test wavelength of $450 \mathrm{~nm}$ with a microplate reader.

The immunoglobulin isotypes were measured by mouse $\mathrm{mAb}$ isotyping reagents (Sigma).

\section{Cell Proliferation Assay}

The growth rate of cells was measured using MTT assay. CD4 ${ }^{+}$ T cells $\left(1 \times 10^{6}\right)$ were cultured in 96-well culture plate with antiCD $3 \varepsilon(2 \mu \mathrm{g} / \mathrm{mL})$ and anti-CD28 mAbs $(1 \mu \mathrm{g} / \mathrm{mL})$. After $48 \mathrm{~h}$ of incubation, each well was added $10 \mu \mathrm{L}$ of MTT solution, and then the absorbance was analyzed by a microplate reader (Thermo Multiskan Ascent, Finland) at $570 \mathrm{~nm}$.

In addition, $\mathrm{T}$ cell proliferation with the $\mathrm{OVA}_{323-339}$-loaded $\mathrm{B}$ cells was analyzed by carboxyfluorescein diacetatesuccinimidyl ester (CFSE, Sigma) dilution methods. CD4 ${ }^{+} \mathrm{T}$ cells $\left(1 \times 10^{6}\right)$ were purified, and then labeled with $5 \mu \mathrm{M}$ CFSE in PBS for 8 min at room temperature and coincubate with $\mathrm{OVA}_{323-339}$ loaded Fut $8^{+/+}$OT-II B cells $\left(1 \times 10^{6}\right)$ for $48 \mathrm{~h}$, and then analyzed by flow cytometric analysis.

\section{Western Blot and Lectin Blot Analysis}

Protein samples were electrophoresed on $10 \%$ polyacrylamide gels. After electrophoresis at $240 \mathrm{~mA}$ for $30 \mathrm{~min}$, proteins were transferred to PVDF membranes. Membranes were blocked in $5 \%$ BSA in TBS-T (10 mM Tris- $\mathrm{HCl}, 150 \mathrm{mM} \mathrm{NaCl}$, and $0.1 \%$ Tween 20) at room temperature for $1 \mathrm{~h}$, and then incubated with the biotin-labeled LCA, which preferentially recognizes the core fucose, or primary Abs in 1\% BSA in TBS-T overnight at $4^{\circ} \mathrm{C}$. After washing, the membranes were covered with the HRP-conjugated streptavidin or HRP-labeled secondary Abs at room temperature for $1 \mathrm{~h}$, and visualized with an ECL system (Amersham).

\section{Immunoprecipitation}

Cell extracts $(500 \mu \mathrm{g})$ were mixed with $20 \mu \mathrm{L}$ of Protein G-Sepharose (50\%) and corresponding Abs, and then incubated at $4^{\circ} \mathrm{C}$ overnight with continuous rotation. After washing three times in lysis buffer, the pull downed samples were boiled for $5 \mathrm{~min}$ in Laemmli sample buffer with or without 2-mercaptoethanol.

\section{T-B Cell Conjugate Formation}

Conjugate formation between T cells and B cells were carried out as described previously with slight modification (21). T cells and $1 \mu \mathrm{g} / \mathrm{mL} \mathrm{OVA}_{323-339}\left(\mathrm{NH}_{2}\right.$-ISQAVHAAHAEINEAGR-COOH)pulsed $B$ cells were mixed at a 1:1 ratio and a quick centrifugation to initiate cell-cell contact. To observe conjugate formation, $B$ cells and T cells were labeled with MHC-II-FITC and TCR $\beta$ PE-Cy5 before mixing. T-B cell conjugates were then analyzed by flow cytometry to determine the percentage of $\mathrm{T}-\mathrm{B}$ cells that had both TCR $\beta$-PE-Cy 5 and MHC-II-FITC positive staining.

\section{Remove of Core Fucose on Surface of T Cells}

Purified CD4 ${ }^{+} \mathrm{T}$ cells $\left(4 \times 10^{6}\right)$ were treated with $100 \mathrm{mU}$ Glyko ${ }^{\circledR}$ $\alpha(1-2,3,4,6)$ Bovine Kidney Fucosidase (GKX-5006, Prozyme), incubate $3 \mathrm{~h}$ at $37^{\circ} \mathrm{C}$ in the reaction buffer. The enzyme reaction was terminated by centrifuging at $2,500 \times g$ for $5 \mathrm{~min}$ and the cells were collected.

\section{Confocal Microscopy}

Conjugate formation between $\mathrm{T}$ cells and $\mathrm{B}$ cells were carried out as described previously with slight modification (21). T cells and $1 \mu \mathrm{g} / \mathrm{mL} \mathrm{OVA}_{323-339}$ pulsed $\mathrm{B}$ cells were mixed at a 1:1 ratio and a quick centrifugation to initiate cell-cell contact. Cell-cell conjugates were subsequently transferred to poly-D-lysine coated coverslips and incubated at $37^{\circ} \mathrm{C}$ for $30 \mathrm{~min}$. Cells were fixed with 4\% PFA for $20 \mathrm{~min}$, and then blocked with 5\% BSA and anti-CD16/CD32 (2.4G2) mAb for $30 \mathrm{~min}$. After washing, cells were stained with anti-MHC-II Ab for $1 \mathrm{~h}$. All images were taken using a spinning disk confocal microscope (Leica).

\section{MACS Magnetic Cell Sorting}

Single splenic cell suspensions were prepared by first grinding the tissues and then by passage through 30- $\mu$ m nylon mesh. Red blood cells were lysed by incubation with $0.14 \mathrm{M} \mathrm{NH} 4 \mathrm{Cl}$ and $20 \mathrm{mM}$ Tris ( $\mathrm{pH} 7.4)$ for $3 \mathrm{~min}$ at room temperature. 
After the lysis of red blood cells, $\mathrm{CD} 4^{+} \mathrm{T}$ cells and $\mathrm{B}$ cells were positively isolated with anti-CD4 Ab and anti-CD45R $\mathrm{Ab}$-conjugated magnetic beads (Miltenyi Biotec). The purified cell populations were detected by fluorescence activated cell sorting analysis.

\section{Flow Cytometric Analysis (FACS)}

Cells were isolated from tissue and incubated with an antiCD16/CD32 (2.4G2) mAb to block Fc $\gamma$ receptors. The cells were stained on ice for $15 \mathrm{~min}$ with several combinations of mAbs, as indicated in the figure legends. Flow cytometry was performed on a FACS-Calibur (Becton Dickinson, Mountain View, CA, USA) and analyzed using FlowJo software (Tree Star).

\section{Induction of Experimental Autoimmune Encephalomyelitis (EAE)}

For EAE induction, Fut $8^{+/+}$and Fut $8^{-/-}$mice were subcutaneously injected with $100 \mu \mathrm{g}$ of myelin oligodendrocyte glycoprotein peptides $\left(\mathrm{MOG}_{35-55}\right)$ emulsified in $\mathrm{CFA}$. Then, mice were injected intraperitoneally with $200 \mu \mathrm{g}$ pertussis toxin (PTX) (List Biological Laboratories) on 0,1 , and 2 days. Clinical assessment of EAE was performed according to the following scale: 0 , no disease; 1, limp tail; 2, hind-limb weakness; 3 , partial hind-limb paralysis; 4, complete paralysis of hind-limbs; and 5, moribund state.

\section{Statistical Analysis}

Student's $t$-test was used for statistical analysis. Data are presented as mean values \pm SEM, or as mean values \pm SD. A probability value of $p<0.05$ was considered significant. ${ }^{\star} p<0.05$, ${ }^{\star *} p<0.01$, ${ }^{* * *} p<0.001$.

\section{RESULTS}

\section{Core Fucosylation Is Significantly Upregulated in the Sera and CD4 $^{+} \mathbf{T}$ Cells of SLE Patients}

Higher circulating levels of ANA were detected in sera from SLE patients. In this study, we found that core fucosylation was dramatically increased in the sera from patients with SLE, as evidenced by LCA, which preferentially recognizes the core fucose structure $(22)(p<0.001)$ (Figures 1A,B). The expression of IgGs was also upregulated in sera of the SLE patients $(p<0.05)$ (Figure 1B). These observations pinpoint the contribution of hyper core fucosylation to SLE severity and pathogenesis.

The hyperactivity of B cells in SLE is T cell dependent, and $\mathrm{CD}^{+} \mathrm{T}$ cell activation plays a crucial role in SLE pathogenesis (23). We found that the percentage of $\mathrm{CD} 4^{+} \mathrm{T}$ cells in the peripheral blood of SLE patients is similar to those of healthy control (Figure 1C). However, the percentage of $\mathrm{CD} 4^{+} \mathrm{CD} 69^{+} \mathrm{T}$ cells was significantly increased in the SLE $(n=17)$ (Figure 1D). Moreover, the enzyme activity of Fut8 was dramatically increased in the $\mathrm{CD}^{+}{ }^{+} \mathrm{T}$ cells isolated from the SLE patients (Figures 1E,F), indicated that increased core fucosylation in SLE patients correlates with $\mathrm{CD}^{+} \mathrm{T}$ cell activation.

\section{Lack of Core Fucosylation Ameliorated EAE Symptoms with Reduced CD4 $^{+}$T Cell Activation}

Wild-type $\left(\mathrm{Fut}^{+/+}\right)$and Fut $8^{-/-}$mice were generated previously (19). Histological analyses of the splenic architecture of Fut $8^{+/+}$ and Fut $8^{-/-}$mice were unremarkable in H\&E staining. The Fut8 products, core-fucosylated $\mathrm{N}$-glycans, are ubiquitously expressed in the Fut $8^{+/+}$spleen, as confirmed by LCA (Figure 2A), while those were abolished in Fut8 ${ }^{-1-}$ spleens. LCA blot analysis also confirmed the knockout of Fut8 expression in the whole cell lysates of Fut8 $8^{-/}$SPLs (Figure 2B). The FUT8 enzymatic activity was not detected in the Fut8 ${ }^{--}$SPLs using HPLC analysis (Figure 2C).

Experimental autoimmune encephalomyelitis is an activated $\mathrm{CD}^{+} \mathrm{T}$ cell-mediated autoimmune disease model. Peptides $\left(\mathrm{MOG}_{35-55}\right)$ and PTX could induce the migration of activated $\mathrm{T}$ cells through the blood-brain barrier and caused several neurologic symptoms. To determine the association between core fucosylation and the activation of $\mathrm{CD} 4^{+} \mathrm{T}$ cells, EAE models were established using Fut8 ${ }^{+/+}$and Fut $8^{-/-}$mice. EAE is actively induced but appear more quickly upon adoptive transfer of activated $\mathrm{MOG}_{35-55}$-specific $\mathrm{T}$ cells in Fut8 ${ }^{+/+}$mice (Figure 2D; Video S1 in Supplementary Material), while Fut $8^{-1-}$ mice showed slight EAE symptoms (Figure 2D; Video S2 in Supplementary Material). The body weights of Fut $8^{+/+}$mice were significantly reduced, but no change was found in Fut $8^{--}$mice during EAE induction (Figure 2D). In addition, the proliferation of $\mathrm{CD} 4^{+}$ $\mathrm{T}$ cells was significantly decreased in Fut ${ }^{-1-}$ EAE mice. Moreover, the proliferation of $\mathrm{CD}^{+} \mathrm{T}$ cells with $\mathrm{MOG}_{35-55}$-loaded $\mathrm{B}$ cells was remarkably reduced by de-core fucosylation (Figure 2E).

\section{Lack of Core Fucosylation Suppressed the IgG Class-Switching by Impaired $\mathrm{CD4}^{+} \mathrm{T}$ Cell Activation}

Flow cytometry analysis revealed that, although $\mathrm{Fut}^{-/-}$mice contained normal proportions of $\mathrm{CD}^{+}$and $\mathrm{CD}^{+} \mathrm{T}$ cell populations in the spleen (Figures $3 \mathbf{A}, \mathbf{B}$ ), they were markedly reduced after OVA immunization contrast with the $\mathrm{Fut}^{+/+}$mice (Figures 3A,B). Immunoglobulin class-switching is a biological mechanism that changes a mature B cell's production of antibody via its B cell receptor from one class to another. For example, from an isotype called IgM to an isotype called IgGs. To illustrate the effects of Fut8 in the class-switching of immunoglobulin, we measured the class-switched (IgGs of different subclasses) and non-switched (IgM) in the sera of Fut $8^{+/+}$and Fut $8^{-/-}$mice using mouse $\mathrm{mAb}$ isotyping reagents. In 4 -week-old Fut $8^{-/-}$mice, the amounts of $\operatorname{IgG}_{1}, \operatorname{IgG}_{2 \mathrm{a}}$, IgG $\mathrm{Ig}_{2 \mathrm{~b}}$, and $\mathrm{IgG}_{3}$ were significantly lower than those in $\mathrm{Fut}^{+/+}$mice after OVA immunization, while those of IgM were relatively normal (Figure 3C). The cytokines, such as IL-4, IL-5, IL-6, and IFN $\gamma$ secreted by CD $4^{+} \mathrm{T}$ cells, contribute to the different IgG class-switching in the mice and human. It is reasonable to consider that the reduced IgG class-switching attributed to the low levels of cytokines secreted by $\mathrm{CD} 4^{+} \mathrm{T}$ cells in Fut $8^{-1-}$ mice (Table 1). In addition, since the TGF receptor signaling was attenuated in the Fut $8^{-/-}$mice (19), the $\mathrm{IgG}_{3}$ 

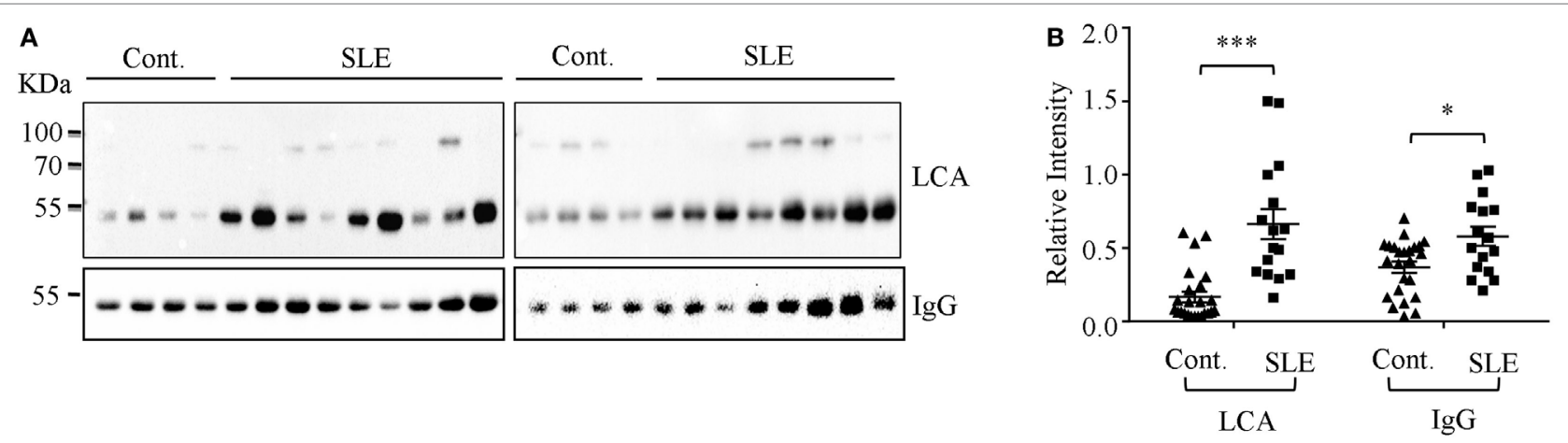

C

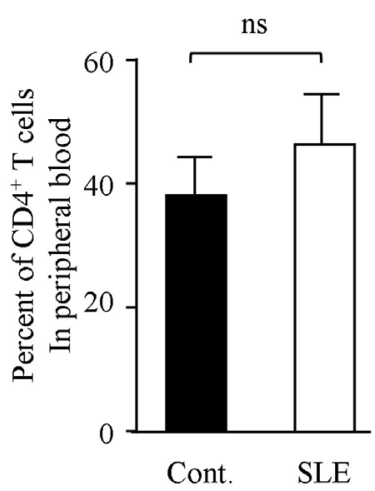

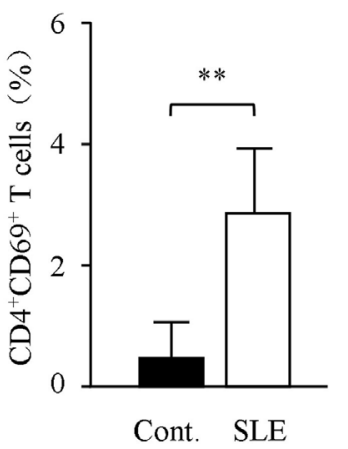

E

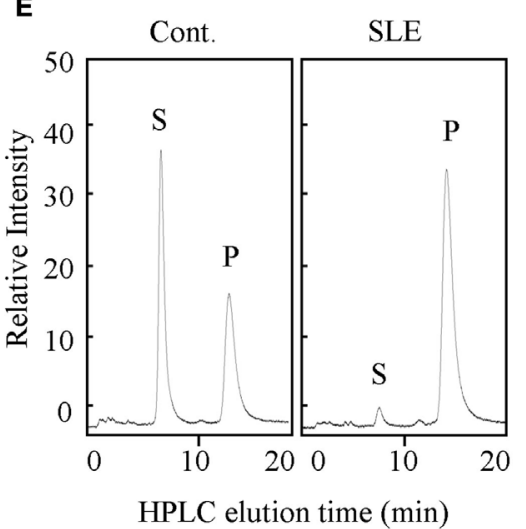

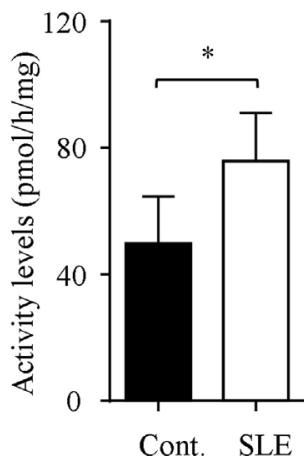

FIGURE 1 | Core fucosylation was significantly increased in the systemic lupus erythematosus (SLE) patients. (A) The sera of SLE patients were analyzed by lens culinaris agglutinin (LCA) blot and Western blot. Plates were incubated with biotin-conjugated LCA (1:20,000). Comparable results were obtained in three independent experiments. (B) Densitometric analysis of the bands of IgG and LCA in sera in SLE patients. Data are shown as mean values \pm SEM $\left({ }^{\star} p<0.05\right.$; $\left.{ }^{* \star *} p<0.001\right)$. (C) The percentage of CD4 ${ }^{+} T$ cells in the peripheral blood of SLE patients. (D) The percentage of CD4+CD69+ $T$ cells in the peripheral blood of SLE patients $(n=17)$. (E,F) FUT8 activities in the CD4 ${ }^{+} T$ cells of SLE patients by high-performance liquid chromatography (HPLC). CD4 ${ }^{+} \mathrm{T}$ cells were isolated with anti-CD4 Ab-conjugated magnetic beads. The sorted cell populations were routinely more than $96 \%$ pure. Five micrograms cell lysates as the enzyme source were mixed with the assay buffer. After incubation at $37^{\circ} \mathrm{C}$ for $8 \mathrm{~h}, 10 \mu \mathrm{L}$ of the supernatant was subjected to HPLC. Activity was expressed as pmol of GDP-fucose transferred to the acceptor per hour per milligram of protein. Data are shown as mean values $\pm \mathrm{SD}\left(n=17 ;\right.$ ns, not significant; $\left.{ }^{\star} p<0.05 ;{ }^{\star \star} p<0.01\right)$. $\mathrm{S}$ is the peptide substrate and $\mathrm{P}$ is the product of fucosylation.

class-switching regulated by TGF signaling was also suppressed in the Fut $8^{-1-}$ mice.

\section{Loss of Core Fucosylation Impaired the Signal Transduction via TCR}

$\mathrm{T}$ cell receptor signaling is very important for $\mathrm{T}$ cell activation. As illustrated in Figure 4A, no different expression of TCR was found in the Fut $8^{+/+} \mathrm{CD} 4^{+} \mathrm{T}$ and Fut $8^{-/-} \mathrm{CD} 4^{+} \mathrm{T}$ cells. Nonetheless, the core fucose of the $\mathrm{N}$-glycans in the molecules was eliminated by a disruption of the Fut8 (Figure 4B). Moreover, the MS spectra of N-glycans released from TCRs were analyzed. It is notable that the high levels of signals were corresponded to the corefucosylated glycans bearing non-, mono-, or di-galactose in the Fut $8^{+/+} \mathrm{CD} 4^{+} \mathrm{T}$ cells, while those were completely disappeared in Fut $8^{-1-} \mathrm{CD} 4^{+} \mathrm{T}$ cells (Figure S2 in Supplementary Material). These results further confirmed in mice that TCRs are highly core-fucosylated proteins and contributes to its activities.

In order to examine the role of core fucosylation in the activation of $\mathrm{CD}^{+} \mathrm{T}$ cells, we isolated $\mathrm{CD} 4^{+} \mathrm{T}$ cells from Fut8 $8^{+/+}$ and $\mathrm{Fut}^{-/-}$mice, and checked the level of core fucosylation.
FACS analysis showed that core fucosylation on the cellular surfaces was abolished in Fut $8^{-/-} \mathrm{CD} 4^{+} \mathrm{T}$ cells (Figure 4C). We compared the phosphorylation levels of $\mathrm{Fut}^{+/+} \mathrm{CD} 4^{+} \mathrm{T}$ cells with Fut $8^{-/-} \mathrm{CD}^{+} \mathrm{T}$ cells in response to costimulations with anti-CD3/CD28 Abs. In those comparisons, the levels of pZAP70 in Fut $8^{-/} \mathrm{CD} 4^{+} \mathrm{T}$ cells were significantly lower than those in Fut $8^{+/+} \mathrm{CD} 4^{+} \mathrm{T}$ cells (Figure 4D). Moreover, the populations of CD69 ${ }^{+}$cells (activated T cells) in Fut $8^{-1-} \mathrm{CD} 4^{+} \mathrm{T}$ cells were lower than those in $\mathrm{Fut}^{+/+} \mathrm{CD} 4^{+} \mathrm{T}$ cells following OVA immunization, while these were similar before immunization (Figure $4 \mathbf{E}$ ). Furthermore, cell proliferation of Fut $8^{-/-} \mathrm{CD} 4^{+} \mathrm{T}$ cells was significantly reduced in response to the stimulation of anti-CD3/ CD28 Abs (Figure 4F).

\section{Core Fucosylation Is Essential for TCR-pMHC Conjugates in CD4+ ${ }^{+}$Cell}

\section{Activation}

$\mathrm{B}$ cells present antigenic peptide with MHC-II molecule as APCs, and $\mathrm{CD}^{+} \mathrm{T}$ cells physiologically recognize a complex of a peptide-loaded MHC-II in T-B cell interaction (18). 
A

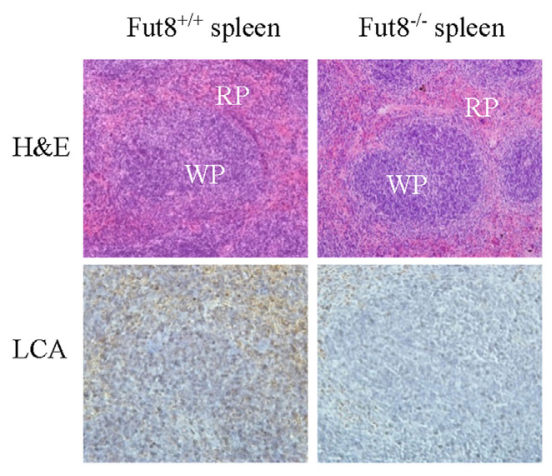

B
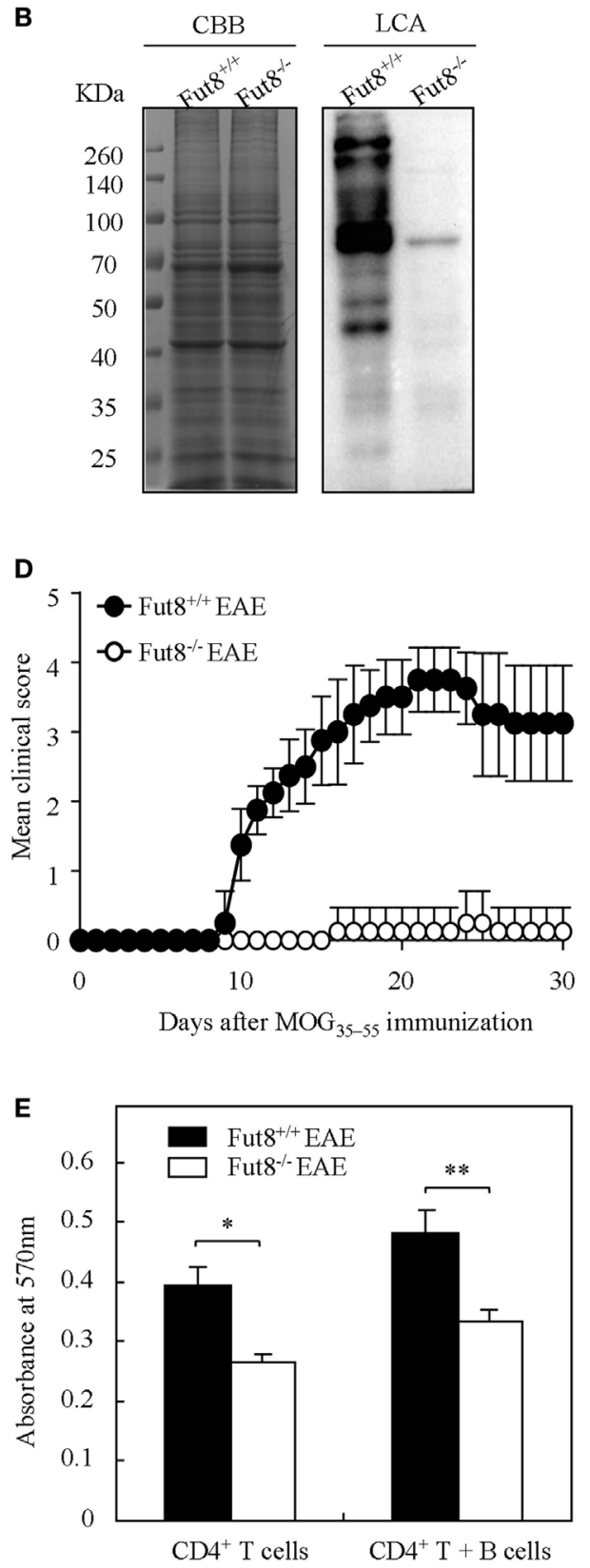

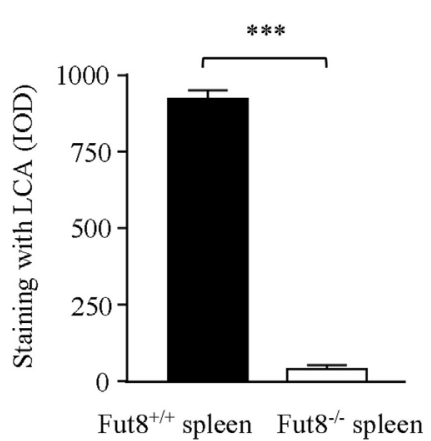

C
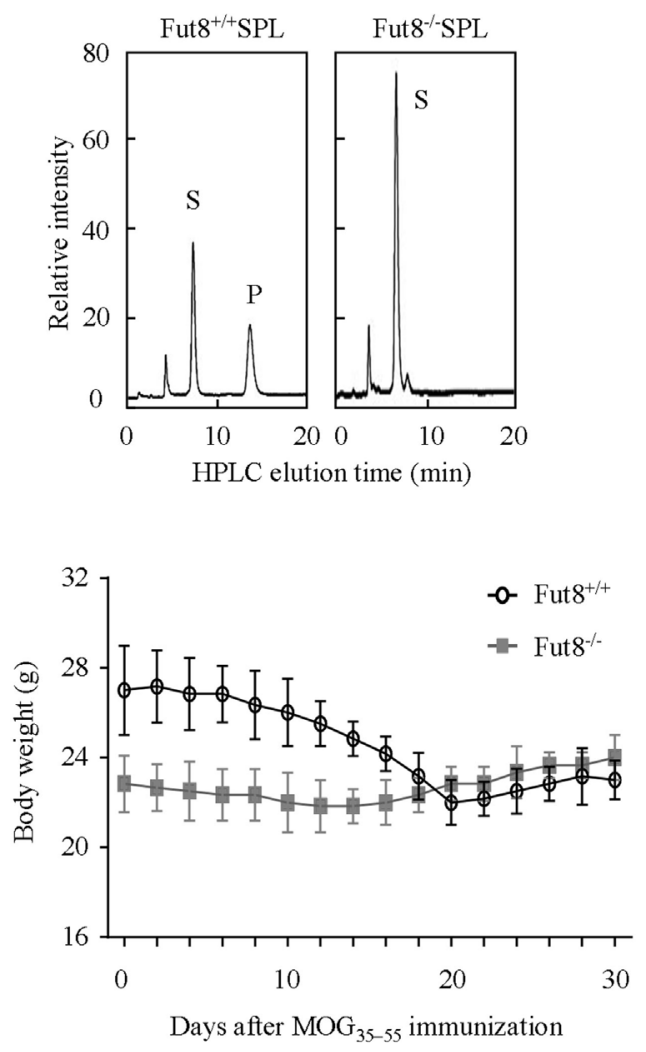

FIGURE 2 | Continued 
FIGURE 2 | The experimental autoimmune encephalomyelitis (EAE) model was slightly induced in Fut8 ${ }^{-/-}$mice. (A) Immunohistochemical analysis of Fut8+/+ spleen and Fut8 ${ }^{-/-}$spleen. The paraffin sections of spleens were deparaffinized and hydrated through a graded series of ethanol to phosphate-buffered saline. One section was assessed by hematoxylin-eosin staining (magnification $\times 200$ ). RP, red pulp; WP, white pulp. Another section was incubated with biotin-conjugated lens culinaris agglutinin (LCA) (1:200) for $1 \mathrm{~h}$. Finally, the slides were visualized with 3,3'-diaminobenzidine. The staining with LCA was showed by integrated optical density analysis. Data are shown as mean values \pm SD $\left({ }^{* * *} p<0.001\right)$. (B) Lectin bolt of Fut8 ${ }^{+/+}$SPL and Fut8 ${ }^{-/-}$SPL. The SPL lysates were run on $10 \%$ SDS-PAGE gel and stained with Coomassie blue staining and LCA (1:5,000). (C) High-performance liquid chromatography (HPLC) analysis of Fut8 activity. Fut8 activities were examined using fluorescence-labeled sugar chain, GnGn-Asn-PABA, as an acceptor substrate, as described in Section "Materials and Methods." The substrate (S) and Fut8 product (P) were eluted at 8 and 15 min, respectively. (D) Disease score of mice in Fut8 $8^{+/+}$and Fut8 ${ }^{-/-}$mice EAE model. EAE induction of Fut8 ${ }^{+/+}$and Fut8 ${ }^{-/-}$mice $(n=7)$. Mice were immunized with $100 \mu \mathrm{g} \mathrm{MOG} \mathrm{MS}_{35}$ peptide in complete Freund's adjuvant and injected with $200 \mu \mathrm{g}$ pertussis toxin, and detected the signs of EAE daily for 30 days. Comparable results were obtained in four independent experiments. Body weights of mice were measured every 2 days after EAE induction of Fut8 ${ }^{+/+}$and Fut8 $8^{-/-}$mice $(n=7)$. (E) Cell proliferation from EAE mice. Purified splenic CD4+ T cells and/or MOG $35-55$ peptide-loaded B cells from EAE models were incubated for $48 \mathrm{~h}$ at $37^{\circ} \mathrm{C}$, and then the cell proliferation was detected by MTT assay. Comparable results were obtained in four independent experiments. Data are shown as mean values $\pm \mathrm{SD}\left({ }^{\star} p<0.05 ;{ }^{* *} p<0.01\right)$.
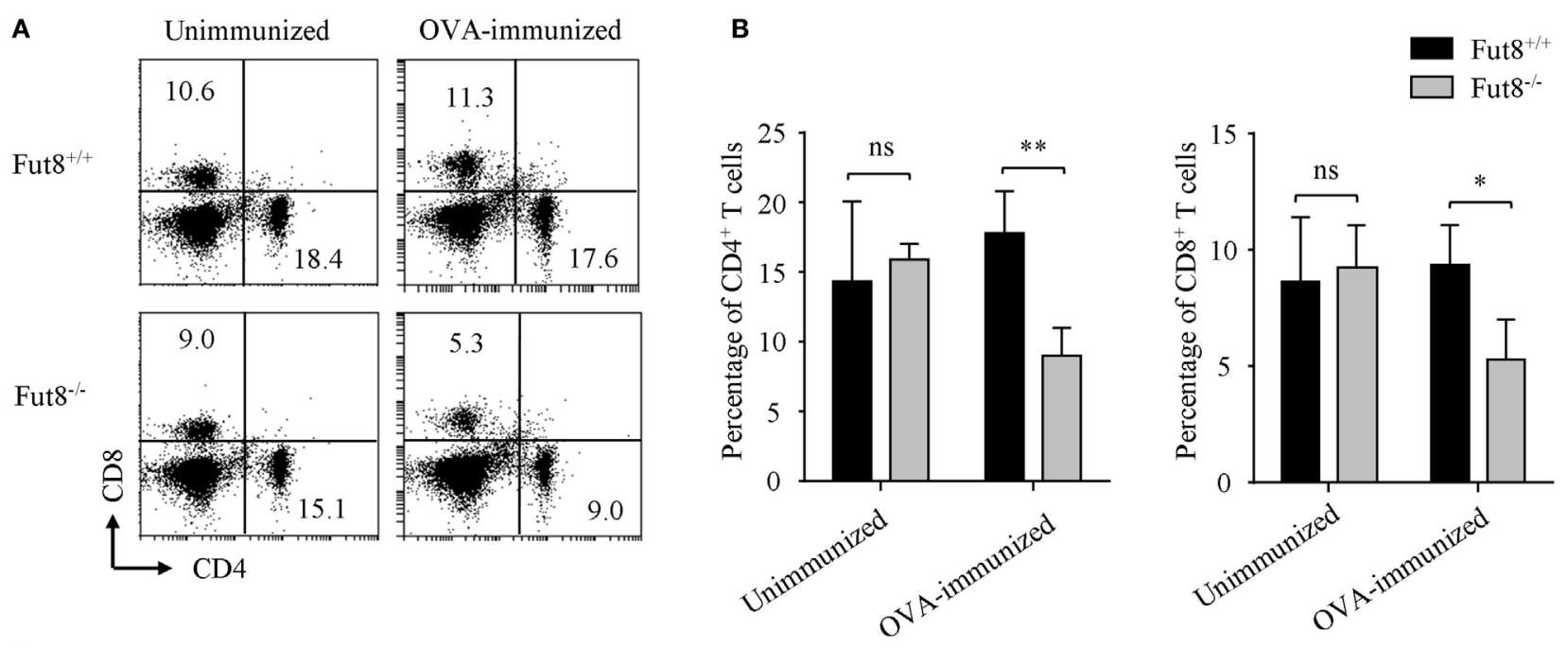

C

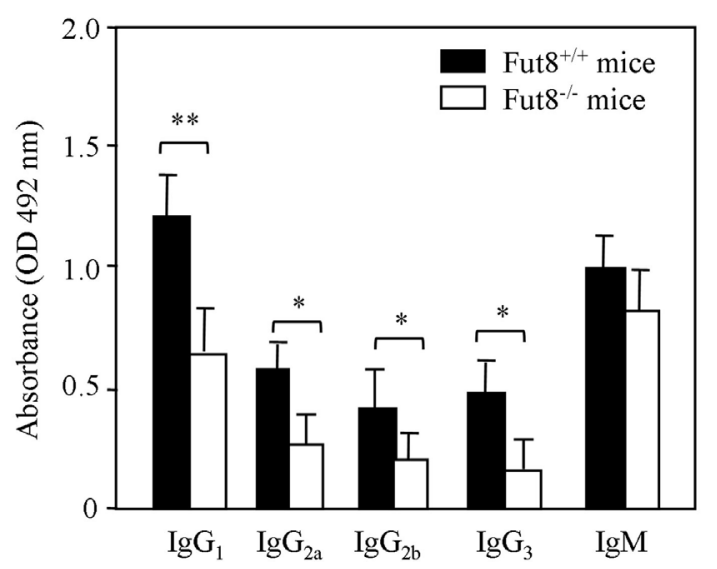

FIGURE 3 | Lack of core fucosylation suppressed the lgG class-switching by impaired CD4+ T cell activation. (A,B) Flow cytometry analysis of the proportion of $\mathrm{CD}^{+}$and CD8 ${ }^{+}$cells. SPLs were obtained from Fut8 ${ }^{+/+}$and Fut8 ${ }^{-/-}$mice with or without OVA immunization. SPLs were filtered through nylon mesh, and resuspended. Numbers indicate the percentage of the total spleen cells within this quadrant, and 10,000 events were acquired for each analysis. Data are representative of three independent experiments. Data are shown as mean values $\pm \mathrm{SD}$ (ns, not significant; $\left.{ }^{*} p<0.05 ;{ }^{* \star} p<0.01\right)$. The number of Fut $8^{+/+} \mathrm{CD} 4{ }^{+} \mathrm{T}$ and Fut8 ${ }^{-/-} \mathrm{CD}^{+} \mathrm{T}$ cells were $(1.29 \pm 0.32) \times 10^{7}$ and $(6.38 \pm 0.89) \times 10^{6}$ of the SPLs, respectively $(n=5)$. (C) Comparison of the levels of serum immunoglobulin isotypes in $\mathrm{Fut8}^{+/+}$and Fut8 ${ }^{-/-}$mice after OVA immunization. The immunoglobulin isotypes are compared by mouse mAb isotyping reagents (Sigma). Comparable results were obtained in three independent experiments. Data are shown as mean values $\pm \operatorname{SD}\left({ }^{\star} p<0.05 ;{ }^{\star \star} p<0.01\right)$.

Therefore, we were interested in determining whether core fucosylation is involved in the TCR sensitivity to pMHC-II. To explore the role of core fucosylation on the TCR interaction with pMHC-II ligands, we crossed Fut $8^{+/-}$mice with OT-II TCR transgenic mice (expressing $\mathrm{CD} 4^{+}$TCR specific for $\mathrm{OVA}_{323-339}$ ), and obtained Fut $8^{+/+}$OT-II and Fut $8^{-/-}$OT-II mice. LCA blots 
TABLE 1 | Gene expression of Fut8 ${ }^{-/-}$SPLs after OVA immunization.

\begin{tabular}{|c|c|c|}
\hline Gene name & Gene access number & Fold change (Fut8 ${ }^{+/+} /$Fut8 $^{-/-}$) \\
\hline \multicolumn{3}{|c|}{ T-cell activation } \\
\hline CD3e & NM-007648 & 2.15 \\
\hline CD4 & NM-013488 & 3.16 \\
\hline CD8 & NM-009858 & 2.51 \\
\hline Cd4OL & NM-011616 & 2.17 \\
\hline IL-2R $\alpha$ & NM-008367 & 3.04 \\
\hline $\mathrm{IL}-4$ & NM-021283 & 2.18 \\
\hline IL-6 & NM-031168 & 2.14 \\
\hline IL-10 & NM-010548 & 2.25 \\
\hline IL-12 & NM-008352 & 3.89 \\
\hline $\mathrm{IFN} \gamma$ & NM-008337 & 3.08 \\
\hline CXCR4 & NM-009911 & 2.04 \\
\hline CXCL12 & NM-001012477 & 2.07 \\
\hline \multicolumn{3}{|c|}{ B-cell activation } \\
\hline CD79a & NM-007655 & 3.35 \\
\hline CD81 & NM-133655 & 2.82 \\
\hline \multicolumn{3}{|c|}{ Cell signaling } \\
\hline MAPKKK & NM_009316 & 2.41 \\
\hline Vav1 & NM-011691 & 3.28 \\
\hline PIK3 & NM-001077495 & 2.36 \\
\hline PKC & NM-008859 & 2.00 \\
\hline Cyclin D3 & NM-001081636 & 3.84 \\
\hline
\end{tabular}

analysis showed that the core fucosylation level of $\mathrm{T}$ and B cells in Fut8 ${ }^{-1-}$ OT-II mice (Figure S3 in Supplementary Material). Since MHC-II on the B cell surface can present peptides for recognition and activation of $\mathrm{T}$ cells, in this study, $\mathrm{B}$ cells were isolated from Fut8 ${ }^{+/+} \mathrm{OT}-\mathrm{II}$ and Fut8 $8^{-/-} \mathrm{OT}-\mathrm{II}$ spleen and incubated with monobiotin-labeled $\mathrm{OVA}_{323-339}$. Although electron density was seen for the structures of I-A ${ }^{\mathrm{d}}$ covalently linked to an $\mathrm{OVA}_{323-339}$, with a single $\mathrm{N}$-glycan (24), the core fucosylation did not affect the peptide presentation abilities of the MHCs between Fut $8^{+/+}$OT-II and Fut $8^{-/-}$OT-II B cells (Figure S4 in Supplementary Material). The $\mathrm{CD}^{+} \mathrm{T}$ cells were then stimulated with $\mathrm{OVA}_{323-339}$ loaded $\mathrm{B}$ cells and subsequent $\mathrm{T}$ cell priming was investigated. The freshly purified ex vivo $\mathrm{CD} 4^{+} \mathrm{T}$ cells were stimulated with the $\mathrm{OVA}_{323-339}$-loaded B cells. As shown in Figure 5A, compared with Fut $8^{+/+} \mathrm{OT}$-II CD $4^{+} \mathrm{T}$ cells, the phosphorylation level of ZAP-70 was dramatically decreased in Fut ${ }^{-1-} \mathrm{OT}-\mathrm{II}$ CD $4^{+} \mathrm{T}$ cells with stimulation of $\mathrm{OVA}_{323-339}$-loaded $\mathrm{B}$ cells. Moreover, to remove the cell-surface fucosylation, the Fut $8^{+/+}$OT-II CD4 ${ }^{+}$T cells were treated with $100 \mathrm{mU}$ Glyko ${ }^{\circledR}$ $\alpha(1-2,3,4,6)$ Fucosidase, which can cleaves $\alpha 1,6$-linked fucose more efficiently than other $\alpha$-fucose linkages (25). The signaling via TCR was significantly suppressed in OT-II CD $4^{+} \mathrm{T}$ cells treated with this fucosidase, when the $\mathrm{T}$ cells were stimulated with $\mathrm{OVA}_{323-339}$-loaded $\mathrm{B}$ cells (Figure 5B), indicated that the Fut8 inactivation results in the less responsive for TCR stimulation with pMHC-II, despite similar TCR expression levels (Figure 4A). Moreover, the population of $\mathrm{TCR}^{+} \mathrm{CD}^{6} 9^{+}$cells was significantly reduced in Fut ${ }^{-1-} \mathrm{OT}-\mathrm{II} \mathrm{CD} 4^{+} \mathrm{T} / \mathrm{OVA}_{323-339}$-loaded B cells compared with Fut $8^{+/+} \mathrm{OT}-\mathrm{II} \mathrm{CD} 4^{+}$T/OVA $323-339^{-}$-loaded B cells (Figure 5C).

To further determine how Fut8 deficiency affects the T-B cell interactions, the communication of $\mathrm{CD}^{+} \mathrm{T}$ cells and $\mathrm{B}$ cells was observed by confocal microscopy. $\mathrm{OVA}_{323-339}$-loaded MHC-II was markedly increased at the site of $\mathrm{T}-\mathrm{B}$ cell contact in Fut $8^{+/+} \mathrm{OT}-\mathrm{II}$ $\mathrm{T}$ cells for $30 \mathrm{~min}$ and was ubiquitous on the Fut $8^{-/}$OT-II T cell surface (Figures 5D,E). Next, T-B cell conjugates were quantitatively analyzed via flow cytometry analysis. Few conjugates of T-B cells were observed in the absence of $\mathrm{OVA}_{323-339}$ peptide, whereas peptide-pulsed $\mathrm{B}$ cells effectively interacted with $\mathrm{CD} 4^{+}$ $\mathrm{T}$ cells. The percentages of T-B cell conjugates in Fut $8^{+/+} \mathrm{OT}-\mathrm{II}$ and Fut $8^{-1}$ OT-II MHC-II ${ }^{+}$TCR $\beta^{+}$cells were 29.4 and $7.4 \%$, respectively (Figures $5 \mathbf{F}, \mathbf{G}$ ), indicated that core fucosylation affected the T-B cell interaction. Moreover, the secretion of IL-2 was reduced in the culture media of Fut $8^{-1-}$ OT-II T-B cells compared with Fut $8^{+/+} \mathrm{OT}-\mathrm{II}$ T-B cells (Figure 5H). Furthermore, the $\mathrm{T}$ cell proliferation with $\mathrm{OVA}_{323-339}$-loaded $\mathrm{B}$ cells was analyzed by CFSE dilution methods. Compared to the proliferation of Fut $8^{+/+} \mathrm{OT}-\mathrm{II}$ CD $4^{+} \mathrm{T}$ cells, those of Fut $8^{-/-} \mathrm{OT}-\mathrm{II} \mathrm{CD} 4^{+} \mathrm{T}$ cells was significantly reduced with the cocultivation of $\mathrm{OVA}_{323-339^{-}}$ loaded Fut $8^{+/+} \mathrm{OT}$-II B cells (Figure 5I). These results indicated that Fut 8 deficiency contributes to attenuated T-B cell communication, and follows attenuated $\mathrm{T}$ cell activation.

To further elucidate the underlying mechanism of the reduced $\mathrm{T}-\mathrm{B}$ cell interaction caused by the disruption of Fut8, $\mathrm{T}$ and $\mathrm{B}$ cell Activation PCR Array was used to compare mRNA expression in Fut8 $8^{+/+}$SPLs with that in Fut8 ${ }^{-/-}$SPLs following OVA immunization. As illustrated in Table 1, the expression levels of four genes (CD3e, CD4, CD8, and CD40L) associated with TCR complex formation, eight genes (IL-2R $\alpha$, IL-4, IL-6, IL-10, IL-12, IFN $\gamma$, CXCL12, and CXCR4) involved in $\mathrm{T}$ cell activation, and two genes (CD79a and CD81) associated with $\mathrm{B}$ cell activation, were downregulated in Fut8 ${ }^{-/-}$SPLs. Moreover, the gene expressions of signal molecules such as MAPKKK, Vav1, PIK3, PKC, and Cyclin D3 were downregulated in Fut8 $8^{-1-}$ SPLs. Since core fucosylation of proteins is an important post-translational process, it is not surprising that many molecules involved in $\mathrm{T}$ and $\mathrm{B}$ cell activation were downregulated in Fut8 ${ }^{-1-}$ SPLs.

\section{DISCUSSION}

The glycosylation and Golgi processing pathways have coevolved with the larger regulatory network that controls $\mathrm{T}$ cell activation. It is not surprising that changes of glycosylation are linked to $\mathrm{AD}$ pathogenesis, such as galactosylation $(26,27)$ and sialylation $(28,29)$. The lower levels of sialylated IgG were found in rheumatoid arthritis (RA) and Wegener's granulomatosis patients, and the sialylated IgG was increased in the sera of patients during remission $(28,29)$. Moreover, loss of galactose residues on $\operatorname{IgG}_{1}$ is showed in the sera of RA patients $(26,27)$. The significant differences of O-glycan on $\mathrm{T}$ helper cells were detected in active SLE patients (30). Core-fucosylated glycans that contain bisecting GlcNAc was increased on the IgG of SLE (31). In this study, core fucosylations were associated with SLE severities, and significantly increased in the $\mathrm{CD}^{+} \mathrm{T}$ cells of SLE patients. Coincidently, previous study by Fujii et al. found that the core fucosylation on $\mathrm{T}$ cells, required for activation of TCR signaling with anti-CD3/CD28 Abs and induction in colitis, is significantly increased in patients with inflammatory bowel disease (32). Hence, one possible consequence of hyper core 

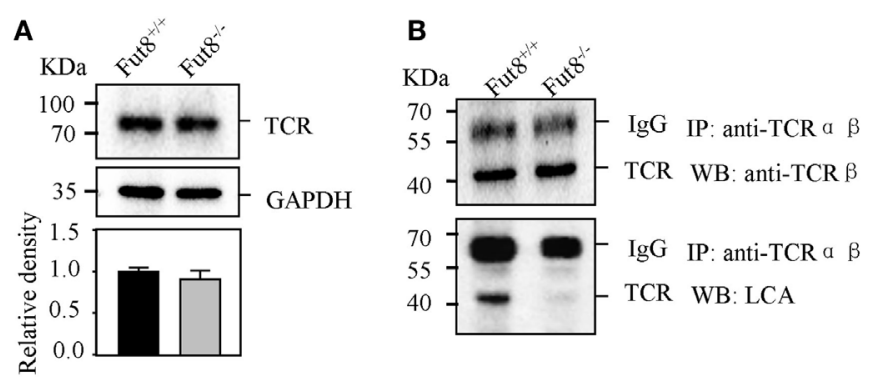
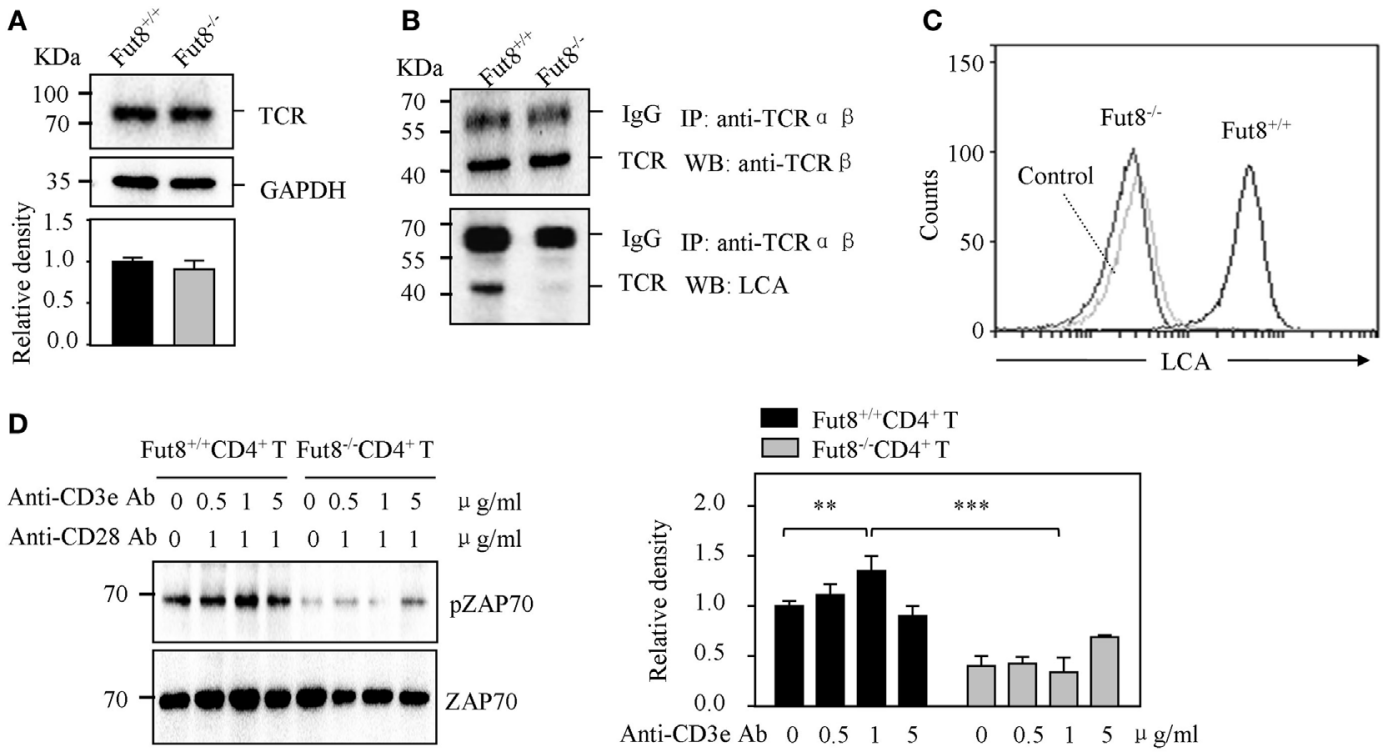

$\begin{array}{llllllllll}\text { Anti-CD3e Ab } & 0 & 0.5 & 1 & 5 & 0 & 0.5 & 1 & 5 & \mu \mathrm{g} / \mathrm{ml}\end{array}$ Anti-CD28 Ab $0 \begin{array}{llllllllll}0 & 1 & 1 & 1 & 0 & 1 & 1 & 1 & \mu & \mathrm{g} / \mathrm{ml}\end{array}$

E
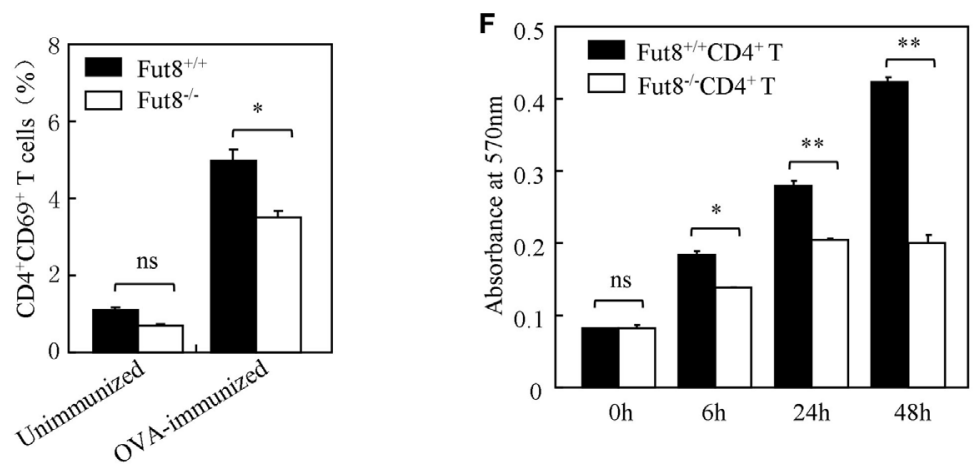

FIGURE 4 | Core fucosylation is required for the activation of CD4+ T cells. (A) Western blots analysis of T cell receptor (TCR). Whole cell lysates were resolved by SDS-PAGE on a $8 \%$ gel, transferred to a PVDF membrane, and probed with anti-TCR $\beta$ Ab. Densitometric analysis of the bands of TCR $\beta$ normalized against GAPDH. (B) Core fucose of N-glycan on TCR $\beta$ in Fut8 ${ }^{-/}$CD4 $4^{+}$T cells was detected by LCA blot. Whole cell lysates were immunoprecipitated with an anti-TCR $\alpha \beta$ antibody. The immunoprecipitates were resolved by SDS-PAGE on a $8 \%$ gel, and probed with the LCA and anti-TCR $\beta$ Ab. (C) Histograms of binding capacity with LCA. Core fucosylation level on the surface proteins of Fut8 ${ }^{+/+} \mathrm{CD} 4^{+} \mathrm{T}$ and Fut8 ${ }^{-/-C D} 4^{+} \mathrm{T}$ cells investigated by FACS analysis. (D) Downregulation of phosphorylated Zap70 in Fut8 ${ }^{-/-} \mathrm{CD} 4^{+} \mathrm{T}$ cells. Purified CD4 ${ }^{+} \mathrm{T}$ cells were serum-starved and were stimulated with anti-CD3/CD28 Abs for 5 min at $37^{\circ} \mathrm{C}$. Cells were lysated in lysis buffer for 15 min on ice. Whole cell lysates were subjected to 10\% SDS-PAGE. The blots were probed by anti-pZAP70 Ab and anti-ZAP70 Ab. Densitometric analysis of the bands of pZAP70 normalized against ZAP70. Data are reported as the mean \pm SD from three independent experiments $\left({ }^{\star \star} p<0.01\right.$; $\left.{ }^{* \star *} p<0.001\right)$. (E) Loss of Fut8 reduced the CD4+CD69+ cells populations in the SPL after OVA immunization. SPLs were isolated from OVA-immunized and unimmunized mice $(n=5)$. Cells were stained with anti-CD69 and anti-CD4 Abs, and then detected by FACS. Data are reported as the mean \pm SD from three independent experiments

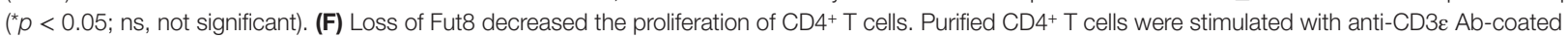
microbeads and anti-CD28 Ab for 0, 6, 24, and $48 \mathrm{~h}$ at $37^{\circ} \mathrm{C}$. The growth rates of CD4+ $\mathrm{T}$ cell were detected by $\mathrm{MTT}$ assay. Data are reported as the mean $\pm \mathrm{SD}$ from three replicate cultures $\left({ }^{\star} p<0.05 ;{ }^{* *} p<0.01\right)$. The absorbance related to the formazan dye level was measured with a microplate reader at 570 nm.

fucosylation-induced $T$ cell activation could be the development of SLE. However, the underlying mechanisms of how core fucosylation regulate $\mathrm{T}$ cell activation with TCR-pMHC interaction remain unclear.

$\mathrm{T}$ cell recognition of pMHC-II ligands on B cells is thought to be carefully coordinated in $\mathrm{CD}^{+} \mathrm{T}$ cells. Conformational flexibility is likely responsible for the high degree of promiscuity or cross-reactivity that is evident in the TCR recognition of pMHCs (33-35). There are two models to explain how TCR-pMHC interactions result in T cell activation $(36,37)$. One model involves an activation threshold based on the occupancy time of the TCR clustering with pMHCs. The alternative model is that $\mathrm{pMHC}$ could induce a specific conformational change of TCR complex and influence the quality of signal transductions via TCRs. Since the core fucose of N-glycan is located on the cellular surface of $\mathrm{T}$ and $\mathrm{B}$ cells, and the core fucosylation could affect the flexibility of N-glycan antenna (38) as well as the conformational stability of proteins (39), it is reasonable to assume that core fucosylation of TCR would affect the geometry and conformation of any TCR-pMHC clusters in the T-B cell 
interactions. Based on a previous study in D. melanogaster cells, the closeness of the interaction of $\mathrm{C} \alpha$ with $\mathrm{C} \beta$ is shown by the hydrogen bonds of the core fucose residue $(6,17)$, suggested core fucose possibly strengthens association of $\mathrm{C} \alpha$ with $\mathrm{C} \beta$. A water molecule also bridges the fucose exocyclic oxygen and the side chain of $\operatorname{Arg}^{150 \beta}$ (17). In this scenario, core fucosylation
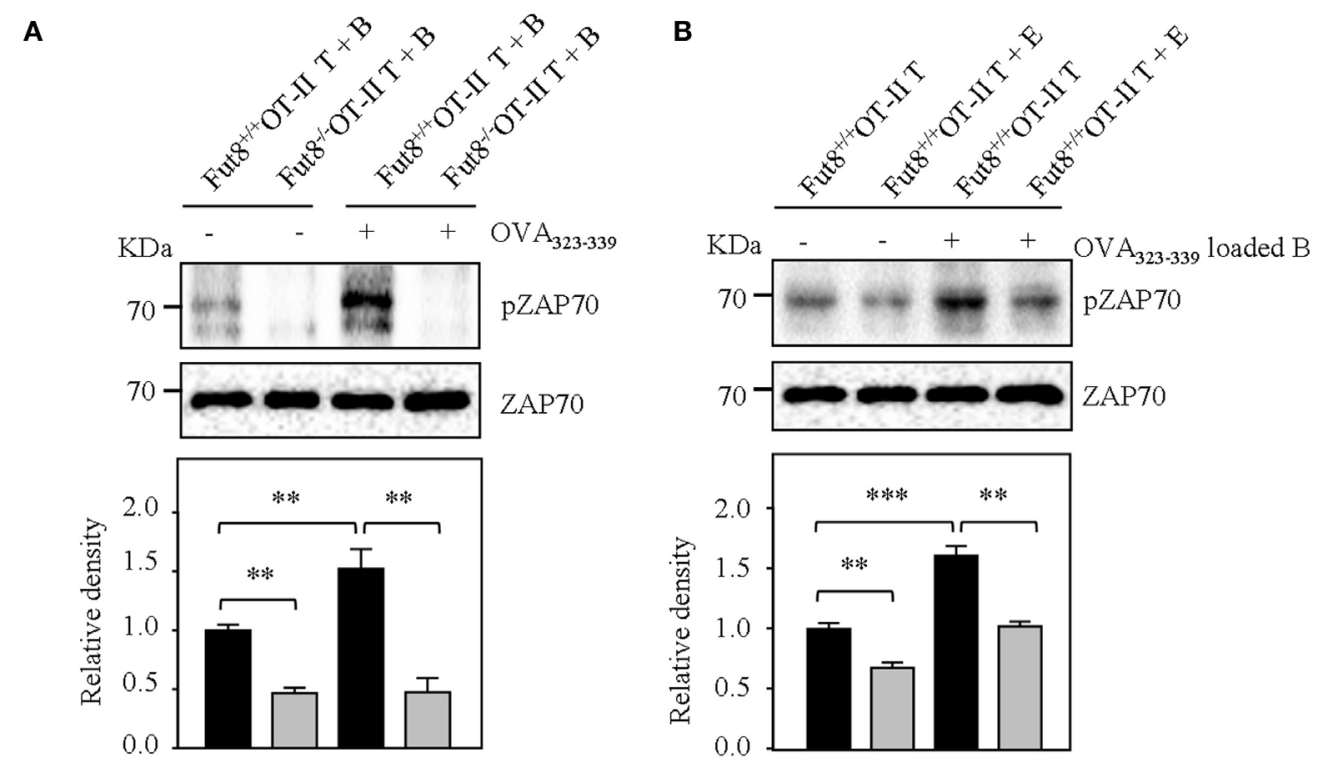

C

D
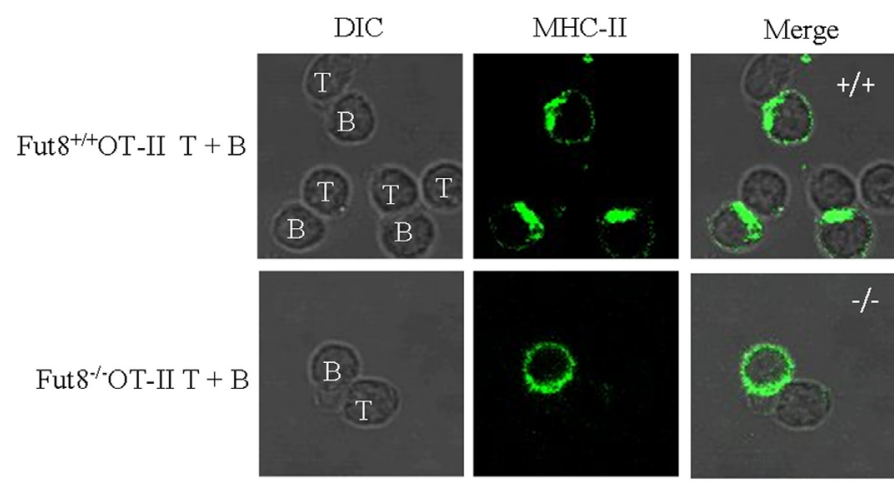

E

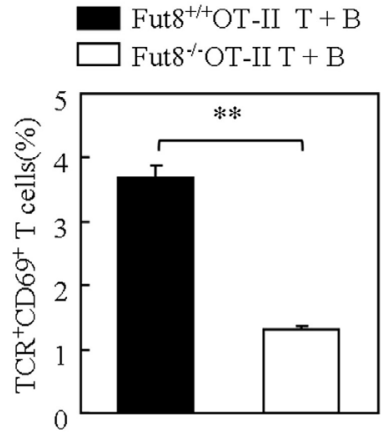

$\mathbf{F}$

G

H
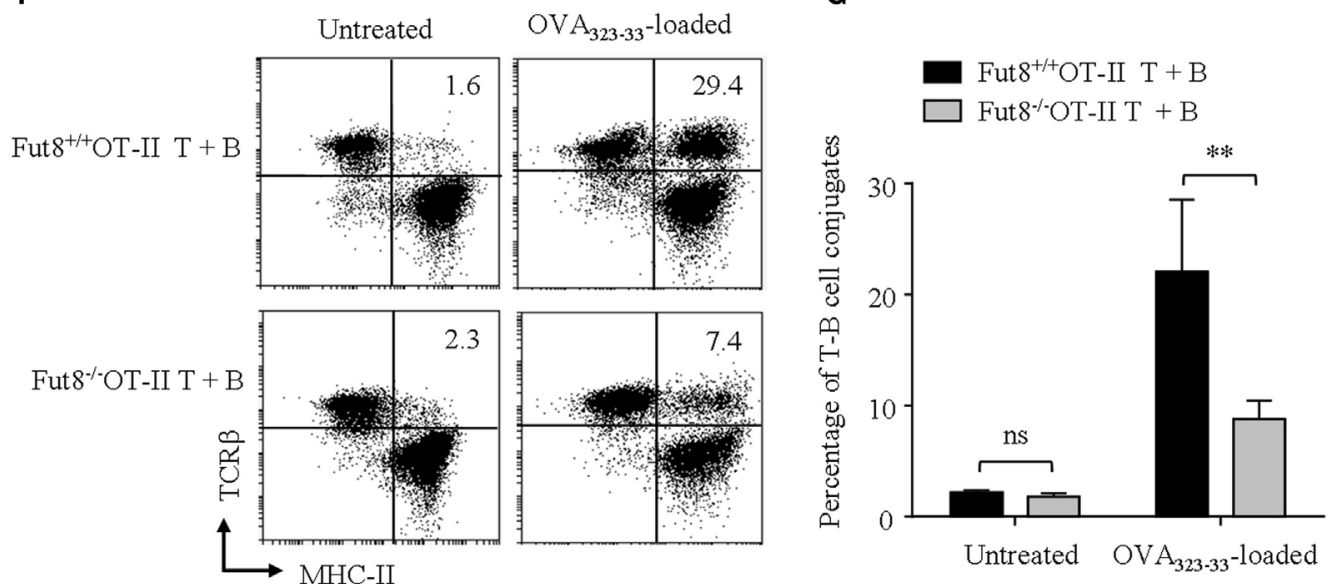

Fut8 ${ }^{+/+}$OT-II T + B

$\square$ Fut8 $8^{-\%}$ OT-II T + B

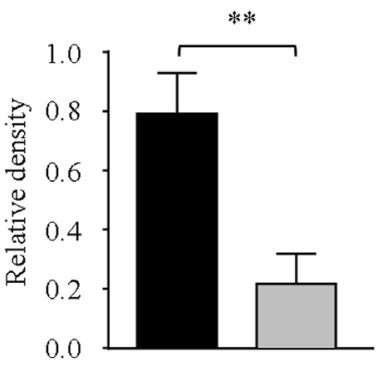

FIGURE 5 | Continued 
I
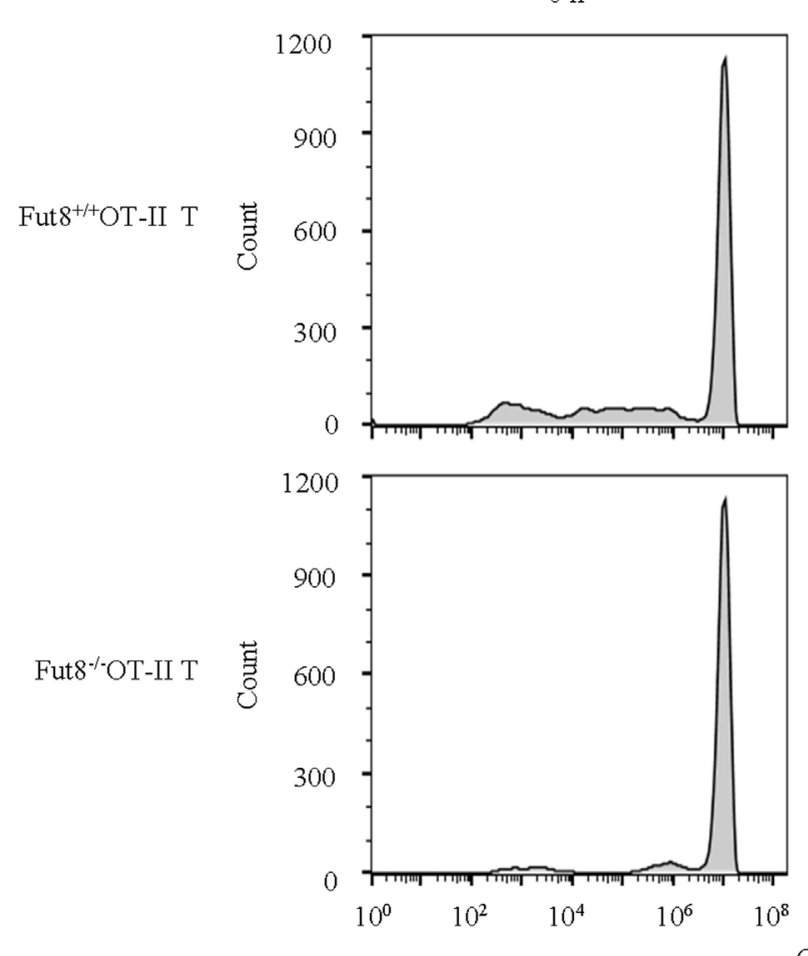

$0 \mathrm{~h}$

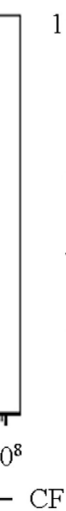

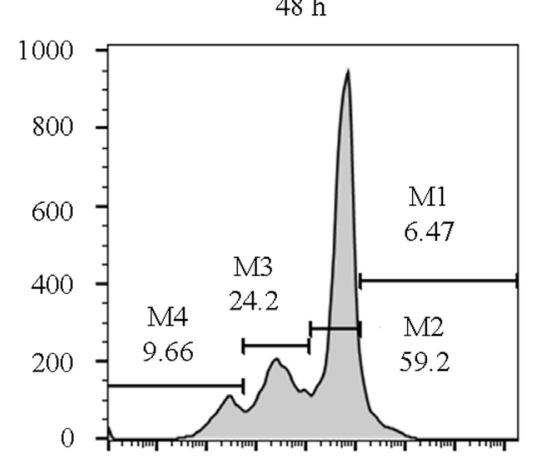

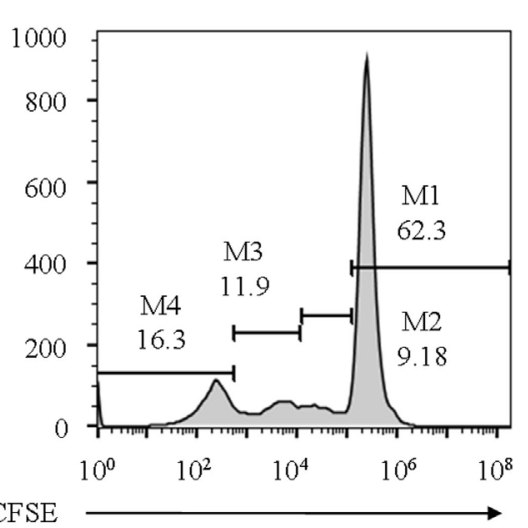

FIGURE 5 | Lack of core fucosulation reduced interaction ability between T cell receptor (TCR) and PMHC-II and impaired the signaling via TCR. (A) ZAP70 phosphorylation of Fut8 ${ }^{+/+} \mathrm{OT}-\mathrm{II}$ T-B cells. (T) B cell conjugate formation was initiated by centrifuging together $\mathrm{CD} 4^{+} \mathrm{T}$ cells with or without $1 \mu \mathrm{mg} / \mathrm{mL}^{\mathrm{O}} \mathrm{VA} \mathrm{A}_{323-339-10 a d e d}$ B cells. The blots were probed by anti-pZAP70 Ab and anti-ZAP70 Ab. Data are representative of three independent experiments. Densitometric analysis of the

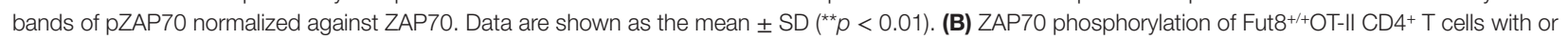
without fucosidase treatment. Purified CD4+ T cells were treated with or without $100 \mathrm{mU}$ Bovine Kidney Fucosidase, and then coincubated with $1 \mu \mathrm{g} / \mathrm{mL} \mathrm{OVA}_{323-339}$ loaded Fut8 ${ }^{+/+O T-I I ~ B ~ c e l l s ~ f o r ~} 30$ min. The blots were probed by anti-pZAP7O Ab and anti-ZAP70 Ab. Data are representative of three independent experiments. Densitometric analysis of the bands of pZAP70 normalized against ZAP70. Data are shown as the mean $\pm \mathrm{SD}\left({ }^{* *} p<0.01 ;{ }^{* * *} p<0.001\right)$. (C) Compare of activation of Fut $8^{+/+} \mathrm{OT}-\| \mathrm{T}+\mathrm{B}$ cells and Fut8 ${ }^{-/-} \mathrm{OT}-\| \mathrm{T}+\mathrm{B}$ cells. CD4+ T cells were conjugated with $\mathrm{OVA}_{323-339}$ loaded B cell. After 30 min, the T-B cells were fixed and stained with anti-TCR $\beta$ and anti-CD69 Abs. Data are shown as mean values \pm SD ( $\left.{ }^{\star *} p<0.01\right)$. (D,E) Distribution of MHC on the T and B cells. The T-B cells were fixed, permeabilized, and stained with Abs to MHC-II (green). Data are from three separate experiments. The ratio of MHC II intensity at the T-B cell conjugate site relative to non-conjugate areas. Data are shown as the mean values \pm SD $\left({ }^{\star *} p<0.01\right)$. (F) FACS analysis of the conjugates between B cells and CD4 ${ }^{+} T$ cells. B cells $\left(\mathrm{OVA}_{323-339-}\right.$-loaded or not loaded) were labeled with anti-MHC-II (FITC) and CD4+ T cells were labeled with anti-TCR $(\mathrm{PE}-\mathrm{Cy} 5)$. T and B cells were quickly mixed and conjugated by a brief centrifugation step. They were then incubated at $37^{\circ} \mathrm{C}$ for $30 \mathrm{~min}$. A representative staining profile with anti-MHC-II and anti-TCR $\mathrm{mAb}$ is shown. The conjugate cells are double positive $\left(\mathrm{MHC}-\mathrm{II}^{+} \mathrm{TCR} \beta^{+}\right)$cells. (G) Percentage of T-B cell conjugates (both MHC-II and TCR $\beta$ positive cells) was calculated. Data are reported as the mean $\pm \mathrm{SD}\left({ }^{* *} P<0.01\right)$ in four independent experiments. (H) The secrition of IL-2 was downregulated in the culture media of Fut8 ${ }^{-/-O T-I I}$ T-B cells. OD values were measured at $492 \mathrm{~nm}$ using a microplate reader. Data are reported as the mean $\pm \mathrm{SD}\left({ }^{* \star} p<0.01\right)$ in three independent experiments. (I) Proliferation of Fut8 $8^{+/+} \mathrm{OT}-\| \mathrm{CD} 4^{+} \mathrm{T}$ cells with $\mathrm{OVA}_{323-339}$ loaded Fut8 $8^{+/+} \mathrm{OT}-\| \mathrm{B}$ cells. Fut $8^{+/+} \mathrm{OT}-\| \mathrm{CD} 4^{+} \mathrm{T}$ cells were purified and labeled with carboxyfluorescein diacetatesuccinimidyl ester (CFSE). Fut $8^{++} \mathrm{OT}-\| \mathrm{CD} 4^{+}$T cells were cocultivated with $1 \mu \mathrm{g} / \mathrm{mL} \mathrm{OVA} \mathrm{A}_{323-339}$ loaded Fut $8^{+/} \mathrm{OT}-\| \mathrm{B}$ cells for $48 \mathrm{~h}$, the divided cells were analyzed by FACS. One representative experiment is shown. M1-M4 indicates daughter cell populations which have subsequently lost half of their CFSE signal.

is expected to provide exciting opportunities to control the TCR function. In the present study, the percentage of T-B cell conjugates $\left(\mathrm{TCR}^{+} \mathrm{MHC}-\mathrm{II}^{+}\right)$was reduced by a factor of 3.97 (29.4/7.4\%) in Fut8 ${ }^{-1-}$ OT-II cells, indicated that the core fucosylation has significant functional implications in TCR-pMHC interaction.

Given the intimate relationship between $\mathrm{pMHC}$ recognition and TCR signaling, the signaling via TCR is also be regulated by glycosylation. It has long been appreciated that Mgat5 deficiency could enhance TCR recruitment to the synapse and results in greater TCR internalization/endocytosis (11). Physiologically,
TCR recognition of $\mathrm{pMHC}$-II ligands on APCs such as dendritic cells and B cells are the most important checkpoint for $\mathrm{CD} 4^{+} \mathrm{T}$ cell activation(40).Engagement of the TCR complexesleads to a signaling cascade of protein tyrosine kinases, such as ZAP70. To explore the role of core fucosylation on the $T$ cell activation, we generated Fut $8^{+/+}$OT-II and Fut $8^{-/-}$OT-II mice. Fut8 deficiency results in the attenuated phosphorylation of ZAP70 in Fut8 ${ }^{-/}$OT-II CD4 ${ }^{+}$ T cells with $\mathrm{OVA}_{323-339}$-loaded $\mathrm{B}$ cells. Also, the phosphorylation of ZAP-70 was significantly reduced in Fut $8^{+/+} \mathrm{OT}-\mathrm{II} \mathrm{CD} 4^{+} \mathrm{T}$ cells by the treatment of fucosidase. Moreover, in Fut $8^{-1-}$ OT-II cells, the number of $\mathrm{CD}^{+} \mathrm{T}$ cells activation $\left(\mathrm{CD} 69^{+}\right)$was decreased 
by a factor of 3.5. The proliferation of the Fut8 $8^{-1-} \mathrm{OT}-\mathrm{II} \mathrm{CD}^{+}$ T cells cocultivated with $\mathrm{OVA}_{323-339}$-loaded $\mathrm{B}$ cells was decreased compared with the Fut ${ }^{+/+} \mathrm{OT}$-II CD $4^{+} \mathrm{T}$ cells. It is conceivable that low $\mathrm{T}-\mathrm{B}$ cell conjugates was proportional to the decreased $\mathrm{T}$ cell activation and proliferation in Fut $8^{-/-} \mathrm{CD} 4^{+} \mathrm{T}$ cells. Core fucosylation is likely to be important in all three proposed stages involved in the T cell activation. First, core fucosylation is essential for the TCR structural formation. Second, core fucosylation of TCR could regulate the recognition of pMHC and affect T cell activation threshold. Third, fucose-specific lectins (41) might participate the events in the T-B cell interaction.

Systemic lupus erythematosus is characterized by the overproduction of auto antibodies, mainly IgG. However, B lymphocyte hyperactivity in SLE is T cell dependent. T cells from SLE patients are activated with a decreased activation threshold and regulated abnormally (32). Indeed, overactive $\mathrm{CD}^{+} \mathrm{T}$ cells had been implicated in the pathogenesis of SLE (42). Although we know that $\mathrm{CD} 4^{+} \mathrm{T}$ cell deregulation contributes to SLE pathogenesis, but the mechanism is still largely unknown. Studies in SLE patients and murine models of lupus have shown enhanced level of IL-4 (43), IFN $\gamma$ (44), and IL- $6(45,46)$. Compared to Fut $8^{+/+}$mice, the IgG classswitching was significantly reduced in the sera of Fut $8^{-/-}$mice after OVA immunization due to low levels of IL-4, IL-5, IL-6, IFN $\gamma$, and TGF secreted by Fut $8^{-/-} \mathrm{CD} 4^{+} \mathrm{T}$ cells. Development of SLE is associated with genetic, hormonal, environmental, and immunological factors, mainly those related to the helper $\mathrm{T}$ cell activation. To investigate the mechanisms of the CD4 ${ }^{+}$ $\mathrm{T}$ cell activation that is important for SLE pathogenesis, we induced the EAE model using Fut $8^{+/+}$and Fut $8^{-/-}$mice. Loss of Fut8 reduced $\mathrm{CD} 4^{+} \mathrm{T}$ cell activation and ameliorated the EAE in Fut $8^{-/-}$mice. Fut $8^{-/-}$mice are resistant to the induction of EAE, whereas Mgat5 $^{-/-}$mice are hypersensitive to it (47). In this regard, Fut8 and Mgat5 function as opposing regulators of $\mathrm{T}$ cell activation thresholds and susceptibility to AD. The hyper core fucosylations are associated with SLE severities, however, whether altered core fucosylation is a consequence or an underlying cause of the SLE cascade remains unclear.

FUT8 is able to modify multiple proteins, followed by the change of their functions. Because the most of immune response molecules are glycoproteins, FUT8 knockdown/knock out affected their function associated with immune response. Okada et al. (10) showed that loss of core fucosylation caused an inhibitory receptor PD-1 deprivation on the cellular surface and augmented $\mathrm{T}$ cell activation, when Fut $8^{-l-} \mathrm{CD} 4^{+} \mathrm{T}$ cells transferred

\section{REFERENCES}

1. Yin Y, Choi SC, Xu Z, Perry DJ, Seay H, Croker BP, et al. Normalization of CD4+ T cell metabolism reverses lupus. Sci Transl Med (2015) 7(274):274ra18. doi:10.1126/scitranslmed.aaa0835

2. Rupanagudi KV, Kulkarni OP, Lichtnekert J, Darisipudi MN, Mulay SR, Schott B, et al. Cathepsin S inhibition suppresses systemic lupus erythematosus and lupus nephritis because cathepsin $\mathrm{S}$ is essential for MHC class II-mediated CD4 T cell and B cell priming. Ann Rheum Dis (2015) 74(2):452-63. doi:10.1136/annrheumdis-2013-203717

3. Reinherz EL, Tan K, Tang L, Kern P, Liu J, Xiong Y, et al. The crystal structure of a T cell receptor in complex with peptide and MHC class II. Science (1999) 286(5446):1913-21. doi:10.1126/science.286.5446.1913 into Rag2 ${ }^{-/-}$mice. Although we did not measure the cell-surface $\mathrm{PD}-1$ expression in the $\mathrm{T}$ cell activation and $\mathrm{T}-\mathrm{B}$ cell interaction, the core fucosylation could regulate the PD-1 expression by modulating TCR signaling strength. Physiologically, there may be some equilibria of the core fucosylation on the TCR and PD-1 to regulate $\mathrm{T}$ cell activation. The complexity of in vivo condition made us cannot conclude the inability for TCR signaling pathway is the sole reason for the $\mathrm{T}$ cell activation, but our study first revealed that Fut8 is essential for TCR-pMHC contact and the following $\mathrm{CD}^{+} \mathrm{T}$ cell activation. The balance between specific and degenerate $\mathrm{T}$ cell recognition of $\mathrm{pMHC}$-II holds important implications for protective immunity versus autoimmunity. With a better understanding of how core fucosylation regulates of the adaptive immune system, its use in therapy for SLE may prove to be a useful intervention.

\section{ETHICS STATEMENT}

All animal work was approved by the Ethics Committee at the Dalian Medical University. The Ethics Committee at the hospital approved the study protocol.

\section{AUTHOR CONTRIBUTIONS}

WL, SM, and SS designed research and performed experiment; ML, ZL, and RY analyzed the experimental data; TM, JG, JZ, and NT corrected paper; WL designed research and wrote paper. All authors reviewed the results and approved the final version of the manuscript.

\section{FUNDING}

This work was supported by the National Nature Science Foundation of China (31570797, 31270864, 30972675), and Natural Science Foundation of Liaoning Province (2015020253), China.

\section{SUPPLEMENTARY MATERIAL}

The Supplementary Material for this article can be found online at http://www.frontiersin.org/articles/10.3389/fimmu.2018.00078/ full\#supplementary-material.

VIDEO S1 | Experimental autoimmune encephalomyelitis symptoms in Fut8+/+ mice.

VIDEO S2 | Experimental autoimmune encephalomyelitis symptoms in Fut8 $^{-/}$mice.

4. Lee KH, Holdorf AD, Dustin ML, Chan AC, Allen PM, Shaw AS. T cell receptor signaling precedes immunological synapse formation. Science (2002) 295(5559):1539-42. doi:10.1126/science.1067710

5. Johnson JL, Jones MB, Ryan SO, Cobb BA. The regulatory power of glycans and their binding partners in immunity. Trends Immunol (2013) 34(6):290-8 doi:10.1016/j.it.2013.01.006

6. Rudd PM, Wormald MR, Stanfield RL, Huang M, Mattsson N, Speir JA et al. Roles for glycosylation of cell surface receptors involved in cellular immune recognition. J Mol Biol (1999) 293(2):351-66. doi:10.1006/jmbi. 1999.3104

7. Daniels MA, Hogquist KA, Jameson SC. Sweet 'n' sour: the impact of differential glycosylation on T cell responses. Nat Immunol (2002) 3(10):903-10. doi:10.1038/ni1002-903 
8. Lowe JB. Glycosylation, immunity, and autoimmunity. Cell (2001) 104(6): 809-12. doi:10.1016/S0092-8674(01)00277-X

9. Rudd PM, Elliott T, Cresswell P, Wilson IA, Dwek RA. Glycosylation and the immune system. Science (2001) 291(5512):2370-6. doi:10.1126/science. 291.5512.2370

10. Okada M, Chikuma S, Kondo T, Hibino S, Machiyama H, Yokosuka T, et al. Blockage of core fucosylation reduces cell-surface expression of PD-1 and promotes anti-tumor immune responses of T cells. Cell Rep (2017) 20(5):1017-28. doi:10.1016/j.celrep.2017.07.027

11. Demetriou M, Granovsky M, Quaggin S, Dennis JW. Negative regulation of T-cell activation and autoimmunity by Mgat5 $\mathrm{N}$-glycosylation. Nature (2001) 409(6821):733-9. doi:10.1038/35055582

12. Lau KS, Partridge EA, Grigorian A, Silvescu CI, Reinhold VN, Demetriou M, et al. Complex $\mathrm{N}$-glycan number and degree of branching cooperate to regulate cell proliferation and differentiation. Cell (2007) 129(1):123-34. doi:10.1016/j.cell.2007.01.049

13. Starr TK, Daniels MA, Lucido MM, Jameson SC, Hogquist KA. Thymocyte sensitivity and supramolecular activation cluster formation are developmentally regulated: a partial role for sialylation. JImmunol (2003) 171(9):4512-20. doi:10.4049/jimmunol.171.9.4512

14. Moore GT, Brown SJ, Winterhalter AC, Lust M, Salvaris EJ, Selan C, et al. Glycosylation changes in hFUT1 transgenic mice increase TCR signaling and apoptosis resulting in thymocyte maturation arrest. Mol Immunol (2008) 45(8):2401-10. doi:10.1016/j.molimm.2007.11.006

15. Kuball J, Hauptrock B, Malina V, Antunes E, Voss RH, Wolfl M, et al. Increasing functional avidity of TCR-redirected $\mathrm{T}$ cells by removing defined $\mathrm{N}$-glycosylation sites in the TCR constant domain. JExp Med (2009) 206(2):463-75. doi:10.1084/jem.20082487

16. Calderon AD, Liu Y, Li X, Wang X, Chen X, Li L, et al. Substrate specificity of FUT8 and chemoenzymatic synthesis of core-fucosylated asymmetric N-glycans. Org Biomol Chem (2016) 14(17):4027-31. doi:10.1039/ c6ob00586a

17. Garcia KC, Degano M, Stanfield RL, Brunmark A, Jackson MR, Peterson PA, et al. An alphabeta $\mathrm{T}$ cell receptor structure at $2.5 \mathrm{~A}$ and its orientation in the TCR-MHC complex. Science (1996) 274(5285):209-19. doi:10.1126/ science.274.5285.209

18. Batista FD, Harwood NE. The who, how and where of antigen presentation to B cells. Nat Rev Immunol (2009) 9(1):15-27. doi:10.1038/nri2454

19. Wang X, Inoue S, Gu J, Miyoshi E, Noda K, Li W, et al. Dysregulation of TGF-betal receptor activation leads to abnormal lung development and emphysema-like phenotype in core fucose-deficient mice. Proc Natl Acad Sci U S A (2005) 102(44):15791-6. doi:10.1073/pnas.0507375102

20. Uozumi N, Teshima T, Yamamoto T, Nishikawa A, Gao YE, Miyoshi E, et al. A fluorescent assay method for GDP-L-Fuc:N-acetyl-beta-D-glucosaminide alpha 1-6fucosyltransferase activity, involving high performance liquid chromatography. J Biochem (1996) 120(2):385-92. doi:10.1093/oxfordjournals.jbchem.a021424

21. Watson AR, Lee WT. Differences in signaling molecule organization between naive and memory CD4+ T lymphocytes. J Immunol (2004) 173(1):33-41. doi:10.4049/jimmunol.173.1.33

22. Tateno H, Nakamura-Tsuruta S, Hirabayashi J. Comparative analysis of core-fucose-binding lectins from Lens culinaris and Pisum sativum using frontal affinity chromatography. Glycobiology (2009) 19(5):527-36. doi:10.1093/ glycob/cwp016

23. Mao L, Hou H, Wu S, Zhou Y, Wang J, Yu J, et al. TIGIT signalling pathway negatively regulates $\mathrm{CD} 4+\mathrm{T}$-cell responses in systemic lupus erythematosus. Immunology (2017) 151(3):280-90. doi:10.1111/imm.12715

24. Scott CA, Peterson PA, Teyton L, Wilson IA. Crystal structures of two I-Ad-peptide complexes reveal that high affinity can be achieved without large anchor residues. Immunity (1998) 8(3):319-29. doi:10.1016/S10747613(00)80537-3

25. O’Flaherty R, Harbison AM, Hanley PJ, Taron CH, Fadda E, Rudd PM. Aminoquinoline fluorescent labels obstruct efficient removal of $\mathrm{N}$-glycan core alpha(1-6) fucose by bovine kidney alpha-l-fucosidase (BKF). J Proteome Res (2017) 16(11):4237-43. doi:10.1021/acs.jproteome.7b00580

26. Parekh RB, Roitt IM, Isenberg DA, Dwek RA, Ansell BM, Rademacher TW. Galactosylation of IgG associated oligosaccharides: reduction in patients with adult and juvenile onset rheumatoid arthritis and relation to disease activity. Lancet (1988) 1(8592):966-9. doi:10.1016/S0140-6736(88)91781-3
27. Ercan A, Cui J, Chatterton DE, Deane KD, Hazen MM, Brintnell W, et al. Aberrant IgG galactosylation precedes disease onset, correlates with disease activity, and is prevalent in autoantibodies in rheumatoid arthritis. Arthritis Rheum (2010) 62(8):2239-48. doi:10.1002/art.27533

28. Matsumoto A, Shikata K, Takeuchi F, Kojima N, Mizuochi T. Autoantibody activity of IgG rheumatoid factor increases with decreasing levels of galactosylation and sialylation. J Biochem (2000) 128(4):621-8. doi:10.1093/ oxfordjournals.jbchem.a022794

29. Espy C, Morelle W, Kavian N, Grange P, Goulvestre C, Viallon V, et al. Sialylation levels of anti-proteinase 3 antibodies are associated with the activity of granulomatosis with polyangiitis (Wegener's). Arthritis Rheum (2011) 63(7):2105-15. doi:10.1002/art.30362

30. Ramos-Martinez E, Lascurain R, Tenorio EP, Sanchez-Gonzalez A, ChavezRueda K, Chavez-Sanchez L, et al. Differential expression of O-glycans in CD4(+) T lymphocytes from patients with systemic lupus erythematosus. Tohoku J Exp Med (2016) 240(1):79-89. doi:10.1620/tjem.240.79

31. Vuckovic F, Kristic J, Gudelj I, Teruel M, Keser T, Pezer M, et al. Association of systemic lupus erythematosus with decreased immunosuppressive potential of the IgG glycome. Arthritis Rheumatol (2015) 67(11):2978-89. doi:10.1002/ art.39273

32. Fujii H, Shinzaki S, Iijima H, Wakamatsu K, Iwamoto C, Sobajima T, et al. Core fucosylation on $\mathrm{T}$ cells, required for activation of $\mathrm{T}$-cell receptor signaling and induction of colitis in mice, is increased in patients with inflammatory bowel disease. Gastroenterology (2016) 150(7):1620-32. doi:10.1053/j. gastro.2016.03.002

33. Alarcon B, Gil D, Delgado P, Schamel WW. Initiation of TCR signaling: regulation within CD3 dimers. Immunol Rev (2003) 191:38-46. doi:10.1034/j.1600-065X.2003.00017.x

34. Mason D. A very high level of crossreactivity is an essential feature of the T-cell receptor. Immunol Today (1998) 19(9):395-404. doi:10.1016/S01675699(98)01299-7

35. Kass I, Buckle AM, Borg NA. Understanding the structural dynamics of TCR-pMHC complex interactions. Trends Immunol (2014) 35(12):604-12. doi:10.1016/j.it.2014.10.005

36. Alam SM, Davies GM, Lin CM, Zal T, Nasholds W, Jameson SC, et al. Qualitative and quantitative differences in $\mathrm{T}$ cell receptor binding of agonist and antagonist ligands. Immunity (1999) 10(2):227-37. doi:10.1016/ S1074-7613(00)80023-0

37. Schamel WW, Arechaga I, Risueno RM, van Santen HM, Cabezas P, Risco C, et al. Coexistence of multivalent and monovalent TCRs explains high sensitivity and wide range of response. J Exp Med (2005) 202(4):493-503. doi:10.1084/jem.20042155

38. Stubbs HJ, Lih JJ, Gustafson TL, Rice KG. Influence of core fucosylation on the flexibility of a biantennary N-linked oligosaccharide. Biochemistry (1996) 35(3):937-47. doi:10.1021/bi9513719

39. Wormald MR, Dwek RA. Glycoproteins: glycan presentation and proteinfold stability. Structure (1999) 7(7):R155-60. doi:10.1016/S0969-2126 (99)80095-1

40. Wolfert MA, Boons GJ. Adaptive immune activation: glycosylation does matter. Nat Chem Biol (2013) 9(12):776-84. doi:10.1038/nchembio.1403

41. Lehrman MA, Hill RL. The binding of fucose-containing glycoproteins by hepatic lectins. Purification of a fucose-binding lectin from rat liver. J Biol Chem (1986) 261(16):7419-25.

42. Moulton VR, Tsokos GC. T cell signaling abnormalities contribute to aberrant immune cell function and autoimmunity. J Clin Invest (2015) 125(6):2220-7. doi: $10.1172 /$ jci78087

43. Mi XB, Zeng FQ. Hypomethylation of interleukin- 4 and -6 promoters in $\mathrm{T}$ cells from systemic lupus erythematosus patients. Acta Pharmacol Sin (2008) 29(1):105-12. doi:10.1111/j.1745-7254.2008.00739.x

44. Gerez L, Shkolnik T, Hirschmann O, Lorber M, Arad G, Kaempfer R. Hyperinducible expression of the interferon-gamma (IFN-gamma) gene and its suppression in systemic lupus erythematosus (SLE). Clin Exp Immunol (1997) 109(2):296-303. doi:10.1046/j.1365-2249.1997.4471345.x

45. Linker-Israeli M, Deans RJ, Wallace DJ, Prehn J, Ozeri-Chen T, Klinenberg JR. Elevated levels of endogenous IL-6 in systemic lupus erythematosus. A putative role in pathogenesis. J Immunol (1991) 147(1):117-23.

46. Grondal G, Gunnarsson I, Ronnelid J, Rogberg S, Klareskog L, Lundberg I. Cytokine production, serum levels and disease activity in systemic lupus erythematosus. Clin Exp Rheumatol (2000) 18(5):565-70. 
47. Grigorian A, Lee SU, Tian W, Chen IJ, Gao G, Mendelsohn R, et al. Control of T cell-mediated autoimmunity by metabolite flux to N-glycan biosynthesis. J Biol Chem (2007) 282(27):20027-35. doi:10.1074/jbc.M701890200

Conflict of Interest Statement: The authors declare that the research was conducted in the absence of any commercial or financial relationships that could be construed as a potential conflict of interest.
Copyright (C) 2018 Liang, Mao, Sun, Li, Li, Yu, Ma, Gu, Zhang, Taniguchi and Li. This is an open-access article distributed under the terms of the Creative Commons Attribution License (CC BY). The use, distribution or reproduction in other forums is permitted, provided the original author(s) and the copyright owner are credited and that the original publication in this journal is cited, in accordance with accepted academic practice. No use, distribution or reproduction is permitted which does not comply with these terms. 